\title{
EXPLORING CHILDREN'S PERCEPTIONS OF WORK AND PLAY IN KINDERGARTEN CLASSROOMS
}

\author{
by \\ Cassandra Calderone \\ B.A, Ryerson University, Toronto, ON, 2012
}

\author{
A Major Research Paper \\ presented to Ryerson University \\ in partial fulfillment of the \\ requirements for the degree of \\ Master of Arts \\ in the program of \\ Early Childhood Studies
}

Toronto, Ontario, Canada, 2013

(C) Cassandra Calderone 2013 


\section{Author's Declaration}

I hereby declare that I am the sole author of this major research paper. This is a true copy of the major research paper, including any final revisions.

I authorize Ryerson University to lend this major research paper to other institutions or individuals for the purpose of scholarly research.

I further authorize Ryerson University to reproduce this major research paper by photocopying or by other means, in total or in part, at the request of other institutions or individuals for the purpose of scholarly research.

I understand that my major research paper may be electronically available to the public. 


\title{
EXPLORING CHILDREN'S PERCEPTIONS OF WORK AND PLAY IN KINDERGARTEN
}

\section{CLASSROOMS}

(C) Cassandra Calderone 2013

Master of Arts

Early Childhood Studies

Ryerson University

\begin{abstract}
Through a qualitative method of inquiry, the purpose of the present study was to explore children's perceptions of work and play in their classrooms using a combination of photography, a categorization task, and semi-structured interviews. Participants included 16 children between the ages of 4 and 6 who were enrolled in kindergarten programs located within childcare centres. Findings show that children made clear distinctions in the characteristics they attributed to work and to play. Children viewed work as tasks that are physical and/or challenging, and often require the production of a final product; whereas play was viewed as enjoyable activities that are freely chosen, involve pretend play, and the manipulation of materials children perceive as toys. Findings from the study can assist educators in developing a deeper understanding of children's perceptions of work and play that may be useful when implementing play-based early childhood programs.
\end{abstract}

Keywords: children's perceptions; perceptions of work and play; play-based programs 


\section{Acknowledgments}

Dr. Aurelia Di Santo: Thank you for believing in my abilities and taking me on as your student. I cannot begin to thank you for your tremendous guidance and support throughout this process. Thank you for always challenging me and pushing me to produce my best work. Your expertise has been invaluable, and your dedication to your students and work is truly inspirational. I have learned so much from you and I am grateful to have had you as my supervisor and mentor.

Dr. Angela Valeo: Thank you for sharing an interest in my work and being part of my oral examination committee. I am honoured to have benefited from your expertise and feedback. Most importantly, thank you for taking the time from your sabbatical to support my project. I am truly grateful.

Dr. Mehru Ali: Thank you for being a part of my oral examination committee and for the support you have provided the MRP students throughout this process.

Child care educators and parents: Thank you for your interest in my research and for welcoming me into your centres.

Fellow Graduates: A special thank you to all my fellow graduate students for their ongoing support. I could not have chosen a better group of people to have shared this experience with. You are all amazing.

Salerno Family: Thank you for opening up your home to me and providing a wonderful space for me to work. Your generosity is truly appreciated.

Mom: Thank you for your unconditional love and support, and for putting up with my insanity over the last few months.

Most importantly, thank you to all the amazing kindergarten children for participating in the study and sharing your ideas with me. This project would not have been possible without you. 


\section{Dedication}

\section{To my Dad,}

Your journey of strength has inspired courage and perseverance throughout this process. I wish you were here to celebrate this achievement with me. 


\section{Table of Contents}

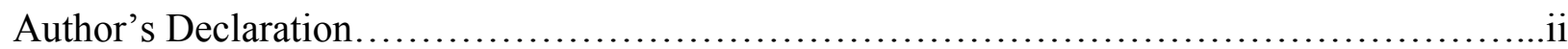

Abstract...........................................................................

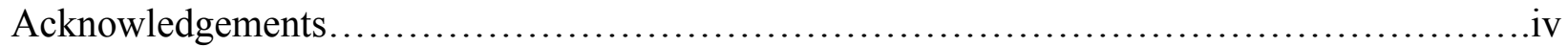

Dedication.........................................................................

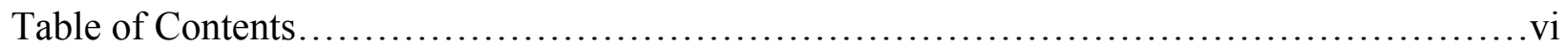

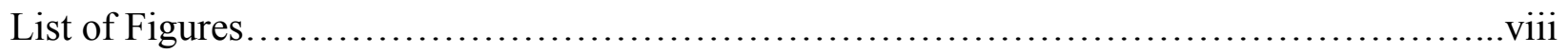

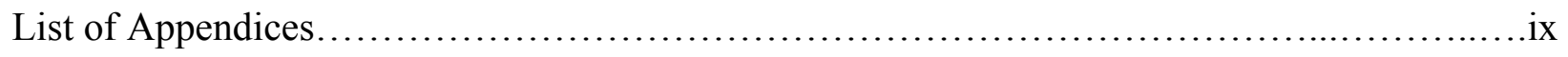

Chapter I: Introduction..........................................................

Theoretical Frameworks.......................................................

Chapter II: Review of the Literature................................................

Overview of Play Theories......................................................

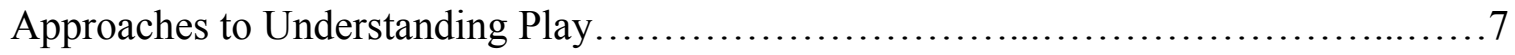

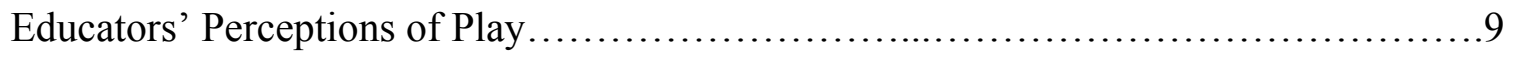

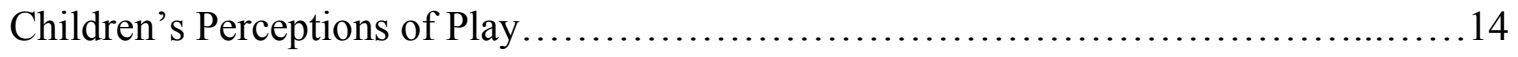

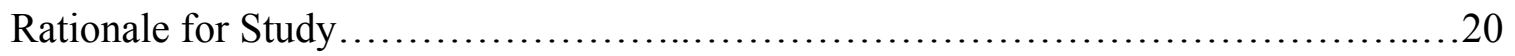

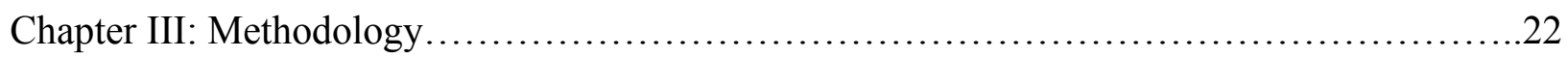

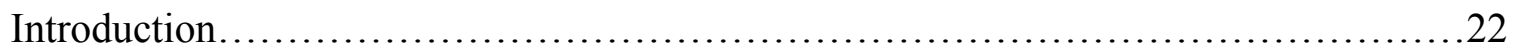

Recruitment Process......................................................23

Research Sites.........................................................24

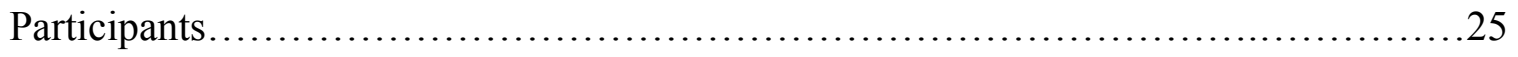

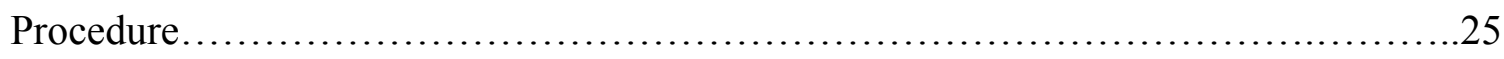

Data Analysis........................................................... 28 
Validity 30

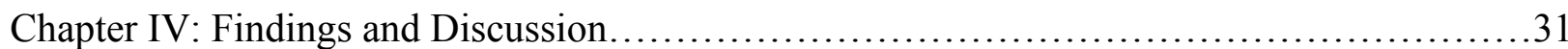

Characteristics Children Attribute to Work in their Classrooms.......................32

Building/Making something ...........................................33

Work First, Play After............................................. 35

Work is Hard ............................................................ 37

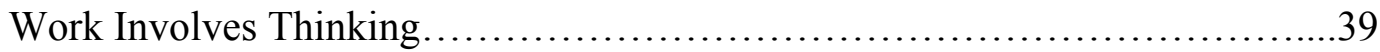

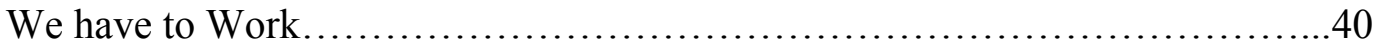

Characteristics Children Attribute to Play in their Classrooms........................42

We get to Play Whatever we Want.....................................43

Pretend Play and Playing with Toys.....................................44

I like to Play because it's Fun..........................................46

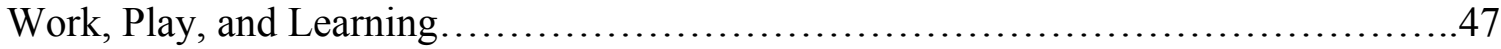

Characteristics Children Attribute to both Work and Play...........................51

Children's Definition of Work and Play........................................52

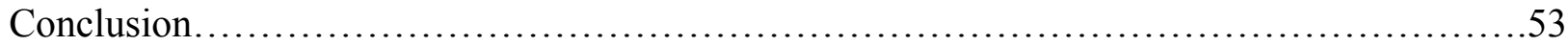

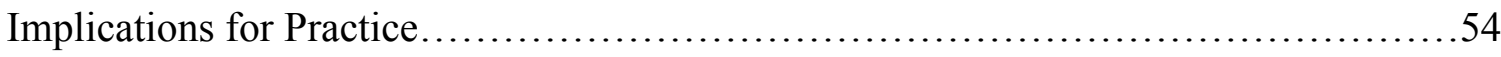

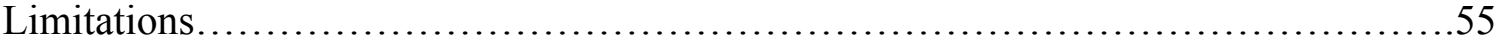

Directions for Further Research..............................................55

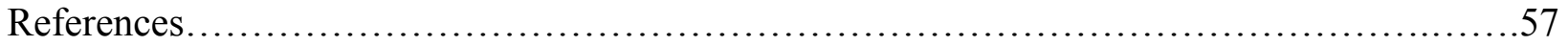




\section{List of Figures}

Figure 1. Luke Skywalker's Spider Diagram.......................................28 


\section{List of Appendices}

Appendix A. Information Letter/Approval Form for Manager/Supervisor......................62

Appendix B. Information Letter/Consent Form for Parents.............................65

Appendix C. Child Assent Agreement................................................68

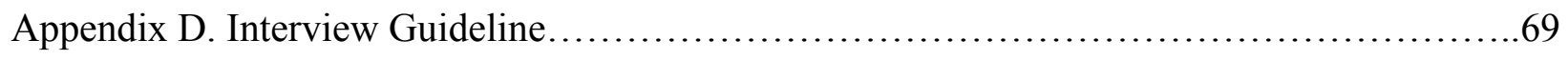




\section{Chapter I: Introduction}

Play within early childhood is present among children across all cultures. Children use play as a vehicle for understanding their world, expressing themselves, and practising skills. Play has sparked the interest of many scholars and theorists who have attempted to understand and describe the nature of children's play. A considerable amount of literature exists that supports the developmental potential of play, as well as the importance of play-based early childhood programs. Due to its complexity, a large body of literature on play has also been devoted to establishing a definition. This has proven to be a challenging task for many scholars, as play is complex, subjective, and can incorporate a wide range of behaviours.

Today, play is considered an integral component of early childhood curricula, and there is widespread acceptance within the field of early childhood studies that play is a medium for learning. Early Learning for Every Child Today: A framework for Ontario early childhood settings (ELECT) states that play is children's way of making sense of the world, and is an effective method of learning for young children (Best Start Expert Panel on Early Learning, 2006). According to the framework, early childhood settings that are play-based and embed learning opportunities within play activities are effective settings that will foster development across all learning domains (Best Start Expert Panel on Early Learning, 2006). This value and emphasis on play is present in a number of early childhood programs and curricular documents used in early childhood settings today.

Adult interpretations and definitions of play have formed the basis of our current understanding about the nature of children's play. The majority of existing research has examined play from the perspective of the adult (e.g., theorists, scholars, educators), and has been based on observations of children, rather than talking directly with them. Educators 
working with young children often provide experiences that fit within the categories or criteria that have been proposed by adult experts, ultimately neglecting the perspectives of children (Howard, 2002).

Children have been subjects of research for many years; however, the nature of their involvement has evolved due to the changing view of childhood within society (Powell \& Smith, 2009). Following the Convention on the Rights of the Child in 1989, childhood was reconceptualized, resulting in an increase in children's participation and activity within society. Children began to be acknowledged as competent social actors, which led to an increase in involvement of children in research on matters that concern them. Children's participation within research has challenged thinking and assumptions made by adults. According to Matthews (2007), including children's voices in research provides a "window" into their lives that adults often assume to know and understand (p. 322). Children's perceptions about their own play are a reflection of their lives and experiences of childhood; however, there is a gap in recent literature examining play from the perspective of the children.

Through a qualitative method of inquiry, the purpose of the present study was to examine children's perceptions of work and play in their kindergarten classrooms which were located within child care centres. The aim of the study was to build on the existing body of literature by adding the perspectives of children. According to Ceglowski (1997), understanding children's perceptions of play is the first step to successful implementation of play-based early childhood programs. With a better understanding of how children perceive play, practitioners may be equipped with knowledge that will assist in the implementation of play-based curriculum programs (Howard, Jenvey, \& Jill, 2006). 


\section{Theoretical Frameworks}

The way in which a researcher perceives the status of children within society impacts the researcher's understanding of children and childhood, as well as his or her methodological choices (Punch, 2002). The conceptual framework adopted by the researcher is the social constructivist approach, as the purpose of the present study was to gain insight into how children construct their own understanding of their world and to develop subjective meanings based on their own experiences (Creswell, 2009). The researcher has acknowledged that the meanings children make of their world are unique, varied, and multiple. The present study relies on children's own perceptions and experiences, and focuses on the specific context of the playbased kindergarten classroom.

The present study has also been framed through the lens of the new sociology of childhood (Matthews, 2007). With roots in children's rights and agency, the new sociology of childhood defines children as social actors capable of understanding and affecting their own societies (Matthews, 2007). Children's participation rights are outlined in the United Nations Convention on the Rights of the Child, particularly in Article 12, which states that children have the right to express their own opinions and have them taken seriously in matters that affect them (UNICEF, 1990). According to Qvortrup (2004), it is essential for adults to recognize children as competent beings with their own opinions, by emphasizing their individualism, autonomy, and cognitive and social capacity. Advocates of the new sociology of childhood recognize the importance and value of talking to children when attempting to understand and study their own experiences (Matthews, 2007). This theoretical perspective acknowledges and accepts children's accounts of their own experiences as an important and valuable source of data. Keeping within the framework of the new sociology of childhood, the aim of the study was to understand children's 
perceptions by involving them as active participants in the research process, as well as acknowledging their abilities to share their own opinions and views.

The theoretical frameworks, in addition to the researcher's professional knowledge, have framed the way in which children and childhood have been perceived throughout the research study. The researcher's academic background in early childhood education, experience in working within play-based early childhood settings, and interest in social research with children, have significantly informed the present study. 


\section{Chapter II: Review of the Literature}

The following chapter provides a presentation and discussion of literature on children's play. The first section begins with an overview of prominent play theories that have had an impact on our current understanding of play. The following sections provide a discussion of research studies that have examined educators' perceptions of play, and studies that have focused on children's perceptions of play. The chapter concludes with a rationale for the present study and presentation of the research questions of focus.

\section{Overview of Play Theories}

Play in early childhood is a complex phenomenon, and has been the topic of considerable research and discussion. Scholars have attempted to gain a better understanding of the reasons why children play, the multiple functions of children's play, and the importance of play for early childhood development and learning. Play theories have evolved over the years as a result of changes in conceptualizations of childhood and best practices in early childhood education.

Early play theories are referred to as classical theories of play, and attempt to identify the reasons why children play. The surplus energy theory and the relaxation theory state that the purpose of play is to regenerate or consume energy (Saracho \& Spodek, 2003). The recapitulation theory and the pre-exercise theory propose that play is a way for children to rehearse socially acceptable skills, and that play resembles the evolution of human race (Saracho \& Spodek, 2003). Classical theories of play are rooted in philosophical ideologies rather than empirical research; however, they have provided the first attempts to developing an understanding of play.

Play was first incorporated into the early childhood curriculum by Friedrich Froebel (17821852), who opened the first kindergarten program in 1839 (Morgan, 1999). Froebel approached 
education from a biological and spiritual perspective, proposing that play contributed to the moral and cognitive development of children. Froebel thought of play as God's gift to children, as well as a tool to equip them with the moral and social traits needed for adulthood (Morgan, 1999). Froebel's contributions have had a significant impact on contemporary play-based early childhood programs; however, it was with the work of philosopher John Dewey (1859-1952) that the modern perception of play as education and learning was developed. Dewey emphasized the need for inquiry-based, child-centered, and experiential learning in the early years. Dewey advocated for the involvement of both teacher-directed learning, while also considering the interests and experiences of children within education (Nutbrown, 2008). Dewey's ideas about play are visible in a number of current early childhood programs including the Full-Day EarlyLearning Kindergarten program in Ontario, as well as the HighScope Early Childhood Curriculum.

Twentieth century theories, referred to as dynamic theories, focus on the content and function of children's play. According to dynamic theories, play is an important vehicle for constructing knowledge and development across all learning domains. Piaget (1896-1980) introduced the constructivist theory, focusing on the cognitive function of play. According to Piaget, children use play to adapt their own experiences with the world into their own body of knowledge (Piaget, 1962). Cognitive development occurs as a result of the child's interaction and experimentation with the environment through play (Piaget, 1962). Aspects of Piaget's theory of play are evident in early childhood programs today, including active participation, and active construction of knowledge through self-discovery. Lev Vygotsky (1896-1934) introduced the social constructivist theory, focusing on the social function of play. According to Vygotsky, play originates from the children's lived experiences. He believed that play has a critical role in 
cognitive development, and assists in the development of social skills (Holzman, 2009).

Vygotsky also acknowledged the significant role that adults and more skilled peers have on guiding children's cognitive development and facilitating higher-level thinking (Holzman, 2009).

The developmental potential of play demonstrated within the dynamic theories is evident in contemporary constructivist practice within early childhood education. Dynamic theories of play have provided a rationale for the importance of play in children's development and supports the link between play and development across all domains.

\section{Approaches to Understanding Play}

It is evident that our understanding of the nature, function, and developmental potential of play has evolved and changed over time, influencing the way in which scholars have studied children's play. In an attempt to establish a comprehensive definition, scholars and theorists have proposed different approaches to understanding and describing play that have had an impact on our current definition of play.

Piaget introduced the categorical approach, stating that there are four different categories of play that children experience in a sequential manner. These four categories of play correspond to the three stages of Piaget's cognitive developmental theory, and become increasingly complex and cognitively demanding as the child develops (Piaget, 1962). The four categories include: practice or functional play ( $0-2$ years), productive play (2-4 years), symbolic play (4-7 years), and games with rules (7-12 years) (Lindon, 2000). However, some scholars have argued that the categorical or developmental approach to understanding play is not effective, as play does not always conform to ages and developmental stages. Rubin, Fein, \& Vandeberg (1983) stated that in order for an activity to be defined as play, certain behavioural characteristics must be present. 
According to Rubin et al. (1983), play is intrinsically motivating, meaning that play is personally motivated by the pleasure embedded in the activity, rather than social demands. Play is processoriented, and more concerned with the activity rather than the end goal. Play also involves freedom of choice, and is not imposed by rules. Finally, play is active, and requires the active engagement of the players (Rubin et al., 1983). Identifying criteria and characteristics of play has assisted in understanding play behaviours and separating them from other activities such as work. However, the criteria approach has also been problematic, as it is difficult to capture the wide range of behaviours associated with play in a set criteria, leaving potential for certain activities to be dismissed.

Scholars have argued that no single operational definition or set of criteria will capture in its entirety the vast behaviours that are associated with children's play. In reaction to this issue, scholars have proposed the continuum approach, where play exists at one end of the continuum, and not-play or work is at the other (Pellegrini, 1991; Wing, 1995). Not every activity is considered either play or work; rather certain characteristics of an activity may be associated with play (e.g., including freedom of choice, active involvement, intrinsic motivation), whereas other characteristics may be associated with work (e.g., teacher-direction, product-orientation). In some cases, when characteristics of both work and play are present, the same activity can be regarded as play in some instances, and not-play in others (Wing, 1995). Therefore, work and play are not examined as polar opposites; rather it is the existence or absence of certain criteria that determines the degree to which an activity is viewed as play.

The theories presented in this review have formed the basis of our current understanding of play. In an attempt to further explore children's play, a large body of research has examined the perceptions of play of educators working with children. 


\section{Educators' Perceptions of Play}

Although play has become a central component of many early childhood programs, the way in which play is incorporated within early childhood settings lies within the control of the educator. Educators' perceptions and understandings of children's play have an impact on how they choose to include play within their classrooms, and can ultimately influence how children themselves perceive play. According to Bennet, Wood, \& Rogers (1997), the classroom setting experienced by children is in large part defined by the educators' understanding of play. Therefore, in order to explore play, it is essential to understand how educators perceive and define play. Research examining educators' perceptions of play has focused on two categories: definitions and characteristics of play, and the educational value of play.

Sherwood and Reifel (2010) conducted a study examining seven pre-service teachers' beliefs about play. Data were collected using hour-long, semi-structured interviews with each of the seven participants. Sherwood and Reifel (2010) found that pre-service teachers had multiple meanings of play and had constructed their own understanding of play based on their beliefs, professional and personal experiences, as well as ideas about universalized definitions of play learned through teacher training. All seven of the pre-service teachers identified only one common characteristic of play: child control. Additional characteristics of play described by the educators were creative, fun, imaginative, socially interactive, and process-oriented (Sherwood \& Reifel, 2010). Although commonalities existed among the characteristics of play described by the participants, no two participants used the same combination of characteristics to describe play, indicating that the participants did not hold a common perception of play (Sherwood \& Reifel, 2010). This study further demonstrates the difficulty in conceptualizing and defining play, and the need for further research examining perceptions and definitions of play. 
Ranz-Smith (2007) conducted a similar study examining four first-grade teachers' perceptions of play in terms of definition, type, and value. Data were collected using interviews and open-ended questionnaires (Ranz-Smith, 2007). When asked to define play, some of the definitions provided by the teachers included activities that are important to children, involve choice, are not forced by the teacher, and are initiated willingly by the children (Ranz-Smith, 2007). Similar to the pre-service teachers in the study by Sherwood and Reifel (2010), these teachers associated play with children's willingness and control. Children's level of choice and control was a defining characteristic in the teachers' descriptions of activities they viewed as play.

Research has indicated that cultural values have an impact on educators' perceptions of play (Wu \& Rao, 2011; Taylor et al., 2004). Using a mixed methods approach, Wu \& Rao (2011) conducted a cross-cultural study examining the differences between German and Chinese teachers' beliefs about play and learning using semi-structured interviews in focus groups. Wu \& Rao (2011) found that German teachers focused more on the social aspect of play. They reported that play involved problem solving, social skills, and adapting to daily life events. On the contrary, Chinese teachers were more concerned with the cognitive aspect of play, emphasizing the ability of play to help children learn shapes, weight, and mathematics (Wu \& Rao, 2011). Similar to the findings from Sherwood and Reifel (2010) and Ranz-Smith (2007), German teachers thought of play as a time with minimal to no teacher instruction or guidance; however, Chinese teachers believed that children learn better through play that is guided by teachers $(\mathrm{Wu}$ \& Rao, 2011). The findings from this study suggest that there are cultural differences in educators' perceptions of play. The German teachers' perceptions emphasized the social aspect of play, whereas the Chinese teachers were more cognitive focused. These findings are 
significant as they indicate that educators' perceptions of play, and how they choose to implement play within classrooms, are influenced by the educational values of their culture.

Cultural differences in educators' perceptions of play are also evident in a cross-cultural comparative study by Taylor et al. (2004), who examined the perceptions of play of 41 Japanese and 41 American teachers. Findings indicated differences in perceptions of play between both cultural groups. Several American teachers mentioned that play is children's work; however, this was not mentioned by any of the Japanese teachers. Additionally, American teachers often used the adjective "fun" to describe play, while very few Japanese teachers mentioned this characteristic. For Japanese teachers, play embodied childhood and the essence of living. Despite cultural differences, two common themes emerged: play is enjoyable, and play is voluntary. Similar to the findings from Sherwood and Reifel (2010), Ranz-Smith (2007), and Wu and Rao (2011), this group of teachers also mentioned children's control as being a defining characteristic of play.

Rothlein and Brett (1987) examined the perceptions of play of children, teachers, and parents to determine whether their perceptions and practices reflected the literature on play. Participants included 103 preschool children, 73 parents, and 60 teachers. Through the use of questionnaires, teachers and parents were asked to define play and describe the ways in which they promote play. Findings indicated that parents and teachers believe that play is fun, amusing, allows for creativity, is non-structured, and allows for learning opportunities. These findings are similar to those from the study by Taylor et al. (2004), who found that teachers associated play with activities that are enjoyable. The teachers in this study also recognized that play involves opportunity for learning; however, this was not the case for the teachers in a study by Pui-Wah (2004). 
Pui-Wah (2004) examined six Hong Kong kindergarten teachers' theories of play-based learning, understanding of play, and approaches used within the classroom through the use of indepth qualitative interviews. The salient finding from this study revealed that teachers described work and play as polar opposites. Play was treated as free time with no learning intentions, and was often used as a reward or time for children to relax after completing work. The most surprising finding from the study was that participants were generally unaware of the opportunities for learning embedded in play activities. It is possible that these findings are linked to the beliefs and values of education and play within Hong Kong. These results are contradictory of the findings from the study by Wu \& Rao (2011), who found that Chinese teachers believed that play was cognitive focused, whereas the teachers in this study seem unaware of the cognitive demand or learning opportunities in play activities.

Cooney, Gupton, and O'Laughlin (2000) conducted a study that yielded results opposite of the findings from Pui-Wah (2004). Cooney et al. (2000) explored kindergarten and grade one children's perceptions of play through observations and interviews with both children and their teachers. The most significant finding from the study was that both teachers and children described some activities as both work and play. One teacher stated that the line between work and play is blended, and has become increasingly "fuzzy" over the years (Cooney et al., 2000, p. 166). Cooney et al. (2000) propose that this could be attributed to the constructivist approach in the particular classroom in the study, as children were encouraged to learn through active involvement in play. This finding could also be linked to the fact that the study was conducted in the United States, as in western countries early childhood programs emphasize the value of play as a central component in learning and development in the early years. 
Many educators struggle with how to implement play in their classrooms, as it is often a challenging task to ensure children achieve curricular goals, while also allowing for childinitiated activity (Ranz-Smith, 2007; Sherwood \& Reifel, 2010). Some educators use play as a classroom management tool or reward, whereas others implement play activities to support children's development and achieve learning outcomes (Sherwood \& Reifel, 2010). One of the most common tensions experienced by educators is the contrasting belief between traditional (teacher-centered) and progressive (child-centered) beliefs (Ranz-Smith, 2007). Many educators support the theoretical basis of play-based learning; however, they struggle with implementing these practices within their classroom. In the study by Rothlein and Brett (1987), all of the teachers stated that they include play within their classrooms; however, the degree of the involvement varied, as only $20 \%$ of teachers indicated that play was an integral part of the school day. Although these findings are quite dated, they are important to highlight, as similar tensions still exist among educators today. In the study by Ranz-Smith (2007), when teachers were asked whether or not they believe curricular goals should be fulfilled through play, participants mentioned that play fosters divergent thinking skills, language and literacy skills, and social emotional skills. However, despite their beliefs, participants expressed that curricular demands stood as a barrier to involving play activities in the classroom, leaving minimal classroom time devoted to play (Ranz-Smith, 2007).

Tensions between educators' beliefs and curricular demands were also demonstrated in a study by Keating, Fabian, Jordan, Mavers, and Roberts (2000) who examined the perceptions of play of the five major stakeholders within the reception class: the head teacher, the reception teacher, the assistant, the parents, and the children. The reception class is the first class in primary school in the United Kingdom, where children are between the ages of four and five- 
years-old. The most significant findings were those from the interviews conducted with the reception class staff. Although all participants had expressed beliefs that play allows for valuable learning opportunities, they all agreed that pressures to adhere to curriculum guidelines inhibited the amount of time allotted to play (Keating et al., 2000). Participants expressed that written tasks were more manageable than play or unstructured activities, as they allow for more concrete evidence of learning. In addition, Keating et al. (2000) found that the strong focus on achieving curriculum standards resulted in perceptions of play as inferior.

The findings from Ranz-Smith (2007) and Keating et al. (2000) are important to highlight, as they demonstrate that although teachers may hold certain attitudes or beliefs about play, they are often constrained by curricular guidelines and expectations. These tensions have an impact on how early childhood programs are delivered, and ultimately how children in these environments may conceptualize and view play.

\section{Children's Perceptions of Play}

It is evident that a wealth of research has focused on examining perceptions of play from the perspective of adults (e.g., theorists, scholars, and educators). According to Tahkyar (1988), in order to fully understand the nature of play, it is essential to determine how children themselves perceive play. The following section provides a discussion of research studies that have focused specifically on children's definitions, thoughts, and perceptions of play.

The majority of research on children's perceptions of play has examined play in relation to work (Cooney et al., 2000; King, 1979; Liu-Yan, Pan-Yuejuan, \& Sun-Hongfen, 2005; Wing, 1995). A common theme found throughout the literature on children's perceptions of play is a definition that involves freedom of choice. King (1979) conducted a research study aiming to explore how kindergarten children define play within their classroom. King (1979) observed 
children while engaged in classroom activities, and then interviewed the children to determine whether or not the activities recorded in the observations were considered "classroom work" or "classroom play" (p.83). The most significant finding was that children classified activities that were freely chosen as play, whereas activities that were assigned or directed by the teacher were labeled as work (King, 1979). King's study serves as an important piece of work, as it was one of the first studies to examine perceptions of play from the perspective of children. It has also influenced the use of the categorization method used in later research regarding children's perceptions of play, including the work of Liu-Yan et al. (2005) who employed a categorization method.

Similar results were found by Wing (1995) who explored children's perceptions of their classroom activities. Using a qualitative method of inquiry, 28 kindergarten, grade 1, and grade 2 children were observed and participated in semi-structured interviews. Wing (1995) found that the most important element that determined whether or not children considered certain classroom activities as work or play was whether the activity was obligatory or not. Children thought of work as something that they had to do, whereas play is something they can or get to do (Wing, 1995). Wing (1995) also addressed the possibility that the children developed these ideas about work and play from the language used by the educators, as children often imitate and repeat language used by adults, and form ideas based on their interactions with others. This possibility is worth exploring, as it is unsure whether or not the children formed these perceptions by observing and imitating the language used by adults. Perhaps probing further and asking children why they believe work is required, whereas play is not, would have revealed information about how these perceptions were formed. 
Liu-Yan et al. (2005) explored five-and six-year-old children's perceptions of play using a photo classification approach and semi-structured interviews. One hundred and fifty children were recruited from 15 different kindergarten classrooms in Bejing. Liu-Yan et al. (2005) found that the presence of toys within the photographic stimuli influenced children's categorizations of activities as work or play. When children were presented with photographs of activities involving toys (materials defined as commercial products by the researchers), $75 \%$ of children labeled the activity as play as opposed to not-play. The presence of toys was a significant factor in determining children's judgments about the nature of whether or not an activity was viewed as play or work.

Similar to the findings from King (1979) and Wing (1995), the second most prominent characteristic reported by the children in the study by Liu-Yan et al. (2005) was freedom. Photographs of activities that involved freedom and minimal teacher involvement (e.g., outdoor play, computer) were categorized as play by the children. The element of teacher control and initiation versus child control and initiation were key-determining variables identified by the children. Similarly, findings from Keating et al. (2000) indicated that children associated play with choice, as activities that children described as play were child-initiated, unstructured activities (e.g., painting, colouring, blocks, sandbox).

Children often judge an activity as play or not play depending on the level of teacher involvement. Similar to the findings from the literature on educators' perceptions of play, this was a common theme found across a number of research studies exploring children's perceptions of play (e.g., Wing, 1995; Howard et al., 2006; \& Liu-Yan et al., 2005). Findings from Wing's study (1995) revealed a similar pattern in children's definitions of play, as they all involved minimal involvement of the teacher. Children identified activities such as painting, blocks, sand 
box, board and computer games, and recess as play. After conducting observations of children involved in these activities, it was evident that the teacher was rarely involved. On the other hand, the level of teacher involvement was significantly higher in activities that children categorized as work (e.g., writing, spelling, math, reading). Observations of these activities revealed that teachers were either directly involved and facilitated these activities (Wing, 1995). Liu-Yan et al. (2005) also found that when the kindergarten children were presented with photographs of an educator teaching directly to children, they more often labeled this activity as not-play as opposed to play.

Howard et al. (2006) conducted a study examining the influence of social context in children's perceptions of play and learning using a categorization task called the Activity Apperception Story Procedure (AASP) (Howard, 2002). Each of the photographic stimuli had one of the following social cues: teacher absence or teacher presence. Ninety-two children between the ages of four and six-years-old were asked to sort twenty-four photographs into four categories: play, not play, learning, or not learning. Findings revealed that the children associated teacher absence with play, as children were significantly more likely to label the photographs where only the children were present as play (Howard et al., 2006). There are 150 participants in this study; therefore, patterns and themes can be generated from the participant's responses. Howard et al. (2006) have also acknowledged the importance of listening to children's voices within their own research study, yet this view of children as reliable and competent participants is not fully demonstrated within the researchers' choice of methodology. The AASP requires children to categorize photographs into pre-determined categories without providing an opportunity to explain their reasoning for their choice. This choice of methodology does not allow for children's voices to be heard. Although Howard et al. (2006) state that the AASP is a 
developmentally appropriate tool to use with kindergarten-aged children, it does not elicit detailed accounts of children's perceptions and experiences.

Chapparo and Hooper (2002) examined 24 six-year-old children's perceptions of work using observations and interviews in focus groups. A drawing activity as well as clips from a videotape of the children's daily routine were used as stimuli to elicit children's views about the meaning they attribute to their work experiences. Findings revealed that children had an individual process in determining what tasks/activities they believed were work and play. When making decisions, children often referred to the type of task being performed. Anything that involved writing, listening, sitting, and thinking was viewed as work. Wing (1995) also found that children identified work as involving cognitive effort, as children often made reference to thinking and concentration when describing activities they viewed as work.

Findings from Chapparo and Hooper (2002) also indicate that children recognize work as tasks that are of high importance, as they often require completion before engagement in more personally desirable activities such as play. Wing (1995) also found that children believed that work relies heavily on completion and the production of a final product. Children recognized that there were certain expectations set by the teacher to successfully complete an activity, whereas other activities did not result in a final product and could be abandoned at any time (Wing, 1995).

A recent study by Anthamatten, Shao-Chang Wee, and Korris (2012) examined how third and fifth grade children from a low-income neighborhood conceptualize play, what aspects of play are important, and the role of play in guiding their activities. Visual methodologies including photo voice questionnaires, as well as focus group interviews were used to collect data from 37 participants. Anthamatten et al. (2012) found that children conceptualized play in a 
largely unstructured form. All participants described areas of the built environment as places that they enjoy playing (e.g., playgrounds, backyards, parking lots). Approximately two thirds of the participants mentioned elements of the natural environment when describing play (e.g., trees, lakes, grass). The findings from this study may be a reflection of the fact that these children were from a low-income neighborhood and do not have access to other types of play, including formal sports, toys, games with rules, or play with technology.

Howard (2002) explored the perceptions of play, work, and learning from 111 children between the ages of three and six using the two-part AASP procedure. The two-part procedure requires children to classify 26 photographic stimuli as either play or work, and learning or not learning. Findings indicated a positive correlation between play and not learning, and work and learning. The second part of the procedure requires children to re-categorize and provide a justification for their choices for a smaller number of photographs. Cues used by the children to justify their responses were teacher presence, positive affect, space, and constraints (Howard, 2002). Similarly, Robson (1993) examined children's perceptions of work, play, and learning through interviews referred to as "extended conversations" (p. 40). Participants included 24 children between the ages of four and five-years-old from three different settings. Findings indicate that children did not associate play with learning, and work was often related to tasks completed while sitting and a desk, and activities initiated by the teacher. This finding is also consistent with the study by Keating et al. (2000), who found that children had a clear understanding of the difference between play and work, as children recognized the learning opportunities in work more often than they did in play.

Although findings from a number of studies have yielded similar results regarding the characteristics children attribute to work and play, not all children categorize activities at 
opposite ends of the work-play spectrum. Wing (1995) proposed a work-play continuum, stating that some elements of activities led children to categorize them as work, and others as play depending on contextual variables (e.g., teacher presence, emphasis on process or product, group or individual activity) (Wing, 1995). Many of the researchers that have explored children's perceptions of play in the early years have assumed that play and work are two distinct categories; however, it is evident that this is not always the case (Wing, 1995; Cooney et al., 2000). Researchers tend to employ methodologies that involve children categorizing activities as work or play with no opportunity to explain or provide a rationale for their choice. In addition, photographic stimuli used for categorization tasks have been created and pre-determined by the researchers. According to the new sociology of childhood, listening to children's voices within research involves providing the opportunity for them to be involved in the research process and to share their views and opinions (Matthews, 2007). The methodologies employed within a number of the studies examined within this review fit children's responses into pre-determined categories, without providing children with an opportunity to provide a rationale and describe their beliefs and thoughts.

\section{Rationale for Study}

The majority of studies on children's perceptions of play presented within this review are quite dated, indicating a gap in current literature. Adult perceptions and interpretations regarding children's play have formed the basis of our current understanding of play, its developmental potential, as well as how to integrate play within the early childhood curriculum. McInnes, Howard, Miles, and Crowley (2011) propose that it is the playful attitude that a child brings to an activity, rather than the observable act of play that truly captures the essence and meaning of play. While certain activities may appear to look like play, adults cannot be sure whether or not 
the children are feeling playful. According to McInnes et al. (2011), play is an internalized construct that only the individual involved in the play experience can understand. In order to conceptualize play in this way, it is essential to add to the body of knowledge the perspective of the main players, the children. There is also a need for current research exploring children's perceptions of play through methodologies that involve children's active participation in research. Exploring children's perceptions of play may also assist educators in implementing play-based early childhood programs, and understanding their role in facilitating children's play experiences. Thus, the purpose of the present study was to examine the following research question: How do children perceive work and play in their kindergarten classrooms? Subsidiary questions include: i) Which activities, learning centres, or materials do children view as work and/or play?; and ii) What characteristics do children attribute to the activities, learning centres, or materials they view as work and/or play? 


\section{Chapter III: Methodology}

\section{Introduction}

Through a qualitative method of inquiry, the aim of the present study was to explore children's perceptions of work and play in their kindergarten classrooms, using a combination of photography, semi-structured interviews, and a task-based activity. Traditionally, children's experiences and perceptions have been explored through the lens and perspective of adults (e.g., researchers, parents, and educators) who have been privileged to speak on the behalf of children (Christensen \& James, 2008). With the introduction of the new sociology of childhood (Matthews, 2007), there has been an increasing interest in listening to children in research that explores their lives and experiences (Christensen \& James, 2008). The present study, framed by the lens of the new sociology of childhood, (Matthews, 2007) aimed to explore children's perceptions of work and play by involving them in the research process.

Interacting directly with children in research calls for the researcher to think carefully about appropriate measures/tools to employ with children (Matthews, 2007). Until recently, research about children has been conducted on children, rather than with them (Hill, Davis, Prout, \& Tisdall, 2004), meaning that children have traditionally been viewed as objects of inquiry, observation, and experimentation, rather than as active participants in the research process (Powell \& Smith, 2009). As a result of theoretical developments within the study of childhood, including the UNCRC, there has been an increased effort to involve children as active participants within the research process.

Photography is said to be an appropriate data collection tool to use with young children, as it is generally novel and exciting for children, and allows them to actively participate in the data collection (Spratling, Coke, \& Minick, 2012). Photographs taken by children also give them a 
sense of power in the research process, as they are in control of what they decide to photograph (Spratling, et al., 2012; Einarsdóttir, 2007). Clark and Moss (2001) highlight the benefit of combining photography with classroom tours, which involves the children taking the researcher on a walk around their classroom setting while taking photographs. Children are in control of the tour and the photographs they take, giving them a sense of power and participation in the data collection. The present study employed a combination of photography and a classroom tour, interviews, and a task-based activity to provide children with multiple modes of expression, and to encourage children's active participation in the data collection and preliminary data analysis.

\section{Recruitment Process}

Upon receipt of approval from Ryerson University's research ethics board, initial recruitment began with telephone calls to the supervisors of five child care centres offering kindergarten programs located in Toronto, Ontario. Child care centres were selected using convenience sampling, and were contacted based on recommendations made by the researcher's academic supervisor. Initial phone calls involved a brief explanation of the study's protocol, as well as its purpose and relevance. Three out of the five centre supervisors expressed an interest in the study. Detailed information packages including supervisor and parental consent forms were e-mailed to each of the three supervisors during the months of May and June 2013 (see Appendix A). Parental information packages and consent forms were distributed by the site supervisors to the parents of the children enrolled in the kindergarten programs during May and June 2013 (see Appendix B). This provided an opportunity for parents to familiarize themselves with the study, ask questions, and provide consent for their children to participate. Parents began returning consent forms approximately one week after distribution. Once parents returned consent forms, data collection dates were arranged with the supervisors at each site based on the 
convenience and schedule of the kindergarten classroom routines. In total, five children were recruited from site one, two from site two, and eight from site three, reaching the desired total of 16 participants.

Although parents had already provided consent, the need to obtain children's assent is essential, as it takes into consideration their rights and power throughout the research process (Balen et al., 2006). A developmentally appropriate child assent agreement was developed and completed immediately before data collection. The assent followed a protocol which included obtaining permission to audio record, use of the children's photographs for the project, as well as informing participants that they could stop at any time and ask their teachers for assistance if needed. If the child expressed an interest in participating in the study, he or she was asked to print his or her name or make a special mark on the agreement form (see Appendix C).

\section{Research Sites}

Three child care centres were recruited as research sites for the present study. Site one provides early learning and childcare programs for toddler, preschool, and kindergarten children. The program philosophy is based on the HighScope curriculum delivered through the Ontario Ministry of Education's ELECT (2006). Site two is a multi-service child care and family support agency, offering child care for children from 18 months to 10 years of age. The centre incorporates a play-based HighScope approach in all activities, with an emphasis on teaching children to make choices and follow through with their plan of action, while also planning according to children's interests and developmental needs. Site three provides child care and programs for children from 18 months to 6 years of age. The kindergarten program follows a play-based curriculum model derived from principles of active learning. Children are given the opportunity to choose what interests them from a combination of both structured and 
unstructured experiences that involve active, play-based learning. All kindergarten classrooms at each site were comprised of learning centres with purposefully placed materials and activities.

\section{Participants}

A total of 16 children, ages 4 to 6 were recruited to participate in the study. The decision to recruit 16 participants took into consideration the time limitations of the major research paper. A total of five participants were recruited from site one, two participants from site two, and eight participants from site three. Participants included 8 females and 8 males, ranging in age from 56 months to 77 months ( $M=65$ months). All 16 participants completed the photography tour, as well as the semi-structured interview and activity. Four children chose to end the interview early due to snack time, outdoor play, or other classroom interests. The interview data collected from these children were still included in the data set.

\section{Procedure}

In order to explore children's perceptions of work and play within their kindergarten classrooms, photography, semi-structured interviews, and a task-based activity were used as data collection tools. According to Punch (2002), an effective method for conducting research with children is using a combination of traditional methods typically used with adults (e.g., interviews) with methods considered more appropriate for children (e.g., photography and activities). By employing methods typically used with adults, children are considered competent beings; however, most children lack experience communicating with adults who are unfamiliar to them. The use of child-friendly methods, including photography and activities allow children to feel more comfortable with the adult researcher (Punch, 2002).

Prior to collecting data with each of the participants, each child was approached individually. After a brief introduction and conversation about the activity he or she was engaged 
in, the child was invited to participate in the study. According to Christensen (2004), it is important for the researcher to inform child participants that the emphasis is on the perspectives and opinions of the children. Thus, it was explained to the children that the focus of the activity was to learn what they thought about work and play. The children were then asked if they would like to participate in the activity. One of the children at site three did not want to participate; therefore another child was randomly selected from the consent forms. Prior to data collection, children were asked to provide the researcher with a pretend name of their choice to use while completing the activity, which was also used throughout data analysis.

Children were provided with digital cameras and were given the opportunity to take the researcher on a tour of their classroom while taking photographs. The participants were given little instruction; the only specific instruction given to the participants was how to operate the digital camera. Children were given the freedom to photograph what ever they pleased; however, due to ethical considerations, children were asked not to photograph other people in the classroom. A number of participants did photograph other children and/or staff members; however, these photographs were removed from the data set in order to protect the rights of the staff and children.

After each child finished the classroom tour, he or she was invited to upload and view the photographs on the researcher's laptop computer. All of the children agreed to view the photographs on the computer. While looking at the photographs on the computer, semistructured interviews consisting of a series of open-ended questions were conducted (see Appendix D). Interviews were held at the children's tables or on the carpet. The location of the interview took into consideration convenience as well as the comfort of the children. Danby \& Farrell (2004) state that power imbalances often exist between adult researchers and child 
participants. In order to reduce the potential for a power imbalance, the researcher sat next to the child at the table or on the carpet, as opposed to sitting across from them, which has the potential to impose feelings of anxiety or discomfort for children (Danby \& Farrell, 2004).

Interviews with children took place while completing a categorization activity using a spider diagram (Punch, 2002; Di Santo \& Kenneally, 2012). The diagram was used as a tool for the children to categorize the photographs of the activities, learning centres, and materials as work and/or play. Each photograph taken by the children was numbered $(1,2,3 \ldots)$. The researcher had corresponding numbers printed out on small pieces of paper. The left side of the spider diagram was labeled work, and the right side was labeled as play. Depending on whether the child classified the photograph as work or play, he or she glued the number that corresponded to the photograph on the appropriate side of the spider diagram (Di Santo \& Kenneally, 2012). Children were asked to provide a rationale as to why certain activities, learning centres, or materials were viewed as work and/or play. An interview guideline was followed; however, questions arose out of the dialogue, and each interview took its natural course. Probes including "why?" and "tell me about this/that" were also used to elicit more information about the children's views. Although children were all asked the same interview questions, they were in control of the course of the interview. According to Spratling et al. (2012), allowing children to speak freely helps establish trust, which is critical to successful interviews. In order to ensure the children's willingness to participate throughout data collection, the researcher looked for cues that demonstrated they no longer wanted to participate. When it was observed that a child was becoming distracted or disinterested, the child was asked if he or she would like to continue the activity, and that it was okay to say "no." 


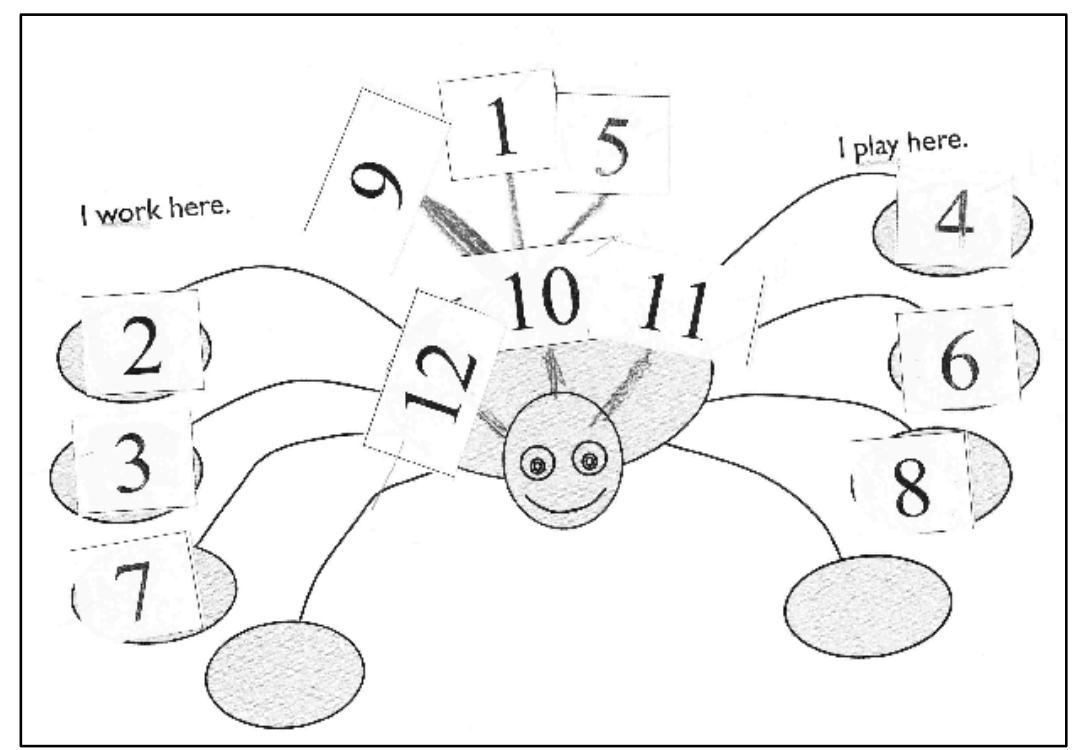

Figure 1. Luke Skywalker's Spider Diagram

\section{Data Analysis}

According to Coad \& Evans (2008), involving children in data analysis aids in addressing power imbalances that exist between the children and the researcher, as well as allowing children to have an active role in the research process. Keeping within the framework of the new sociology of childhood (Matthews, 2007), the present study aimed to actively involve children in in the preliminary data analysis by categorizing their photographs as work and/or play. Preliminary data analysis began during the semi-structured interview as the researcher and children viewed, discussed, and classified the photographs. The purpose of the spider diagram was not only for the children to classify the photographs as work and/or play, but also to assist in the organization of data.

Data analysis was conducted using thematic analysis. Thematic analysis is a method of analysis used in qualitative research for identifying, interpreting, and reporting on themes or patterns found within the data (Braun \& Clarke, 2006). Once data were collected, it was organized and prepared for analysis. Audio recordings of interviews were transcribed, and the 
spider diagrams, photographs, transcriptions, and field notes were all organized according by participant and site. Phase one of data analysis involved reading through the transcriptions twice in order to get a general sense of, and become familiar with the data. Open coding was used to develop codes on the basis of emerging information, rather than analyzing the data using predetermined codes (Creswell, 2009). During this process, the researcher wrote down ideas, words, or phrases that emerged. Notes were also made on the corresponding child's spider diagram with information from the transcripts.

Phase two of the coding process involved the generation of 14 codes from the notes made during phase one (e.g., like/love to play, play is fun, pretend play, play and choice, voluntary, obligatory, toys/games, hard work, work first play later, making/building something, thinking and work, work and writing/sitting at a table, work and learning, and play and learning). Each code was assigned a colour and a name, and the data were revisited and coded based on the 14 codes. During the third phase of coding, the original 14 codes were collapsed into 9 codes (e.g., work and building/making, hard work, work first play later, work and thinking, work, play, and learning, have to work, play and choice, play is active, and positive feelings and play. During the final stage of analysis, the nine codes reflected four themes. Sub-themes were also formed within the themes. In order to ensure authenticity of children's views, sub-themes were named based on the views and perceptions shared by children, rather than terms provided by the researcher.

Themes were labeled with a consistent term that was used throughout the analysis. Theme one: characteristics children attribute to work. Sub-themes include; building and making something; work first, play after; work is hard; work involves thinking; we have to work). Theme two: characteristics children attribute to play. Sub-themes include; we get to play what 
ever we want; pretend play and playing with toys; I like to play because it's fun. Theme three: work, play, and learning. Theme four: characteristics children attribute to work and play. Themes are presented in descriptive narrative passages involving a detailed discussion and direct quotes from each child (Creswell, 2009).

\section{Validity}

Steps were taken during the data collection and organization process to ensure validity in the research. During the interviews, the researcher repeated children's responses in order to ensure accuracy. The researcher also waited for the children to confirm their responses. This helped to ensure that the researcher heard the children's responses correctly, as well as ensure accuracy in the audio-recordings. Once audio-recordings were transcribed, they were checked twice for potential errors. 


\section{Chapter IV: Findings and Discussion}

The purpose of the present study was to examine children's perceptions of work and play in their kindergarten classrooms, which were located within child care centres. The following section will present findings and discussion addressing the two subsidiary questions: i) Which activities, learning centres, or materials do children view as work and/or play?; and ii) What characteristics do children attribute to the activities, learning centres, or materials they view as work and/or play? Given that our current understanding of play is based primarily on adult perceptions and definitions, the aim of this study was to begin to develop a definition of what is considered work and what is considered play in the classroom based on the children's perspectives.

During the interviews, children were given the opportunity to categorize the photographs of the activities, learning centres, and/or materials they took in their classrooms. A spider diagram was used as a tool for children to categorize the photographs (see chapter III). Keeping within the framework of the new sociology of childhood, the purpose of the spider diagram was to give children a sense of control in the research process by involving them in the preliminary data analysis.

Children's responses from the categorization task were analyzed in order to examine which activities, learning centres, and/or materials they viewed as work and/or play. The only learning centre and material that were consistently viewed as work and/or play by the children were the creative arts centre and the dollhouse. Four children photographed the creative arts centre and all of them viewed it as work. Four children also photographed the dollhouse, and all of them viewed it as play. A discussion of these findings, including children's explanations as to why they viewed the creative arts centre as work, and the dollhouse as play, are presented within the 
following sections under characteristics children attribute to work, and characteristics children attribute to play.

With the exception of the creative arts centre and the dollhouse, analysis of children's responses from the spider diagram categorization task did not indicate consistent patterns between activities, learning centres, and materials that children viewed as work and/or play. Of the 11 children who photographed the blocks, $31 \%$ viewed them as play, $25 \%$ viewed them as work and play, and $13 \%$ viewed them as work. This variation in responses existed for a number of activities, learning centres, and materials (e.g., book centre, drawing centre). Children's views appeared to be highly individual and were based on their experiences with the activities and materials, or in the learning centres they had photographed. These findings emphasize the importance of combining the use of the categorization task with the semi-structured interview in order to elicit children's perceptions and justification for their categorizations. The interviews encouraged children to share why they believed a certain activity, learning centre, or material was work and/or play. Patterns in the characteristics children attributed to work and play became apparent as children began providing rationales for their choice of work and/or play. These patterns were organized into four themes: characteristics children attribute to work in their classrooms; characteristics children attribute to play in their classrooms; work, play, and learning; and the characteristics children attribute to both work and play in their classrooms

\section{Characteristics Children Attribute to Work in their Classrooms}

It appears from the findings that commonalities exist in children's perceptions of the characteristics they attribute to the activities, learning centres, and materials they viewed as work. Characteristics children attributed to work are discussed in the following sub-themes; 
building and making something; work first, play after; work is hard; work involves thinking; and we have to work.

Building and making something. When describing activities, learning centres, and materials that the children viewed as work, they often made reference to the physical effort involved. Physical effort, including building or making something was mentioned by eight children when describing 19 separate photographs. As mentioned in the previous section, the four children who photographed the creative arts centre all viewed it as work. Black viewed both the drawing centre and creative arts centre as work, and when asked why, she stated, "because you're making something." Darth Vader and Pink also viewed the creative arts centre as work and shared that they were working to "make something." Similarly, when describing why he viewed the creative arts centre as work, Luke Skywalker stated, "because I need to make something." These four children viewed the creative arts centre as work because it involved making and creating something.

Building was also a reoccurring theme in the children's responses. Five children mentioned building when explaining why a certain activity was work. In fact, Black made reference to the absence of building when explaining why she believed a learning centre was play. She viewed the computer as play because "you aren't building anything." Blue also made a similar association, when she stated that she viewed the blocks as work because they involve building. When providing a rationale as to why he believed the sand box was work, Darth Vader also made reference to building, stating, "we're working with building...because we are building something."

The association between work and building/making something was also present in activities, learning centres, and materials that children viewed as both work and play. Children referred to 
the building/making aspect of an activity as work, and the action or behaviour that occurs once the creation is complete as play. Projector expressed that he viewed the blocks as work and play, and when asked to provide a rationale, he stated, "cause the work one is the part of building, and the play is part of playing with them." Projector identified the building aspect of the blocks as work, and play as what is done with the blocks once the structure/creation is complete. Similarly, Luke Skywalker viewed the playdough as both work and play, because "you work when you make something, and then you play with that." He also identified the blocks as possessing similar attributes of work and play, stating that first he "builds stuff" and that he only plays when he is done building.

The association these children made between work and building/making something is somewhat inconsistent with previous literature, as children have typically associated physical involvement with play rather than work (Cooney et al., 2000, Liu-Yan et al., 2005, Wing, 1995). Physical involvement was present in other activities, learning centres, and materials that children viewed as play (e.g., dollhouse, dramatic centre); however, what differed in what children viewed as work was the physical labour aspect involved in the activities. It is possible that children recognize the physical force and strength required in these work activities, as the blocks and sandbox both involve carrying objects, while the play dough involves using physical strength to roll out the dough and manipulate it into shapes and objects. It is also a possibility that this perception of work may be related to children's knowledge of occupations involving physical labour that have been observed through social interactions with parents and other adults, materials such as books, and the media. Representations of construction workers and builders are seen throughout children's literature on community workers and in children's television programs (e.g., Bob the Builder). 
There is a gap in the literature regarding children's perceptions of work as something that involves physical labour, as children have not typically associated work with building or making. Research has indicated that children often associate work with sedentary activities that involve sitting at tables, listening, and writing (Liu-Yan et al. 2005; Chapparo \& Hooper 2002; Robson, 1993), whereas activities that involve physical activity have been typically associated with play. This finding adds to the body of literature on children's perceptions of work, stating that children do not solely view work as something that is sedentary, and that work can also involve physical activity. It is also possible that this finding is related to the play-based nature of the kindergarten classrooms, where there is a high level of active and physical engagement with materials. It would be beneficial to explore this finding through further research to examine why children view building/making an object as work and if other children share similar beliefs. Perhaps children enrolled in non play-based programs that are highly structured and teacher-directed may have different views regarding the association of work and physical activity. Further exploration of the association between work and building/making something would provide insight into how children's perceptions of work are influenced by children's literature, media, social interactions, and educational environment.

Work first, play after. Children's descriptions of work as building/making something also suggest that there is a link between work and the production of a final product. It appears from the findings that when children are engaged with activities, learning centres, and materials they viewed as work, they had an end product in mind. This was evident in Projector's response, who reported that when working with the blocks, he is "working to make something." When Darth Vader described his photograph of the blocks, he said that he was "working to make a stream." Similarly, when sharing why he believes the blocks are work, Diego stated, "when I'm working 
is to make something that goes vroom vroom." As mentioned in the previous section, the four children who photographed the creative arts centre and viewed it as work all stated that it was work because they are making something. It is possible that these children may have also associated the creative arts centre with work, as they are working to produce a final product.

The idea of work as being goal-oriented was also evident in children's descriptions of activities, learning centres, and materials they viewed as both work and play. The fact that work was referred to as building/making, and play as the behaviour that occurs once the building is complete, suggests that these children believe that work is something that must be completed before engaging in play. It is important to consider how this idea of work first, play after has become part of children's perceptions, as it provides insight into children's views of the status and value of work and play in their classroom. If work is something that must be completed before play, this suggests that work is of more importance and of higher priority than activities children view as play. It is possible that this perception is something that has been reinforced by educators in their classrooms. Perhaps educators have portrayed the message that work is something that is goal-oriented and requires completion, and once the children complete their work they are able to engage in play.

These findings are consistent with the literature, stating that children recognize that work relies heavily on completion and the presentation of a final product, whereas play activities could be abandoned at any time. Findings from the literature have also indicated that children view work as important tasks that require completion before engaging in more desirable play activities (Rothlein \& Brett, 1987; Chapparo \& Hooper, 2002; Wing, 1995). This literature is quite dated, and it appears as though in kindergarten classrooms today, children still perceive work as something that is product-oriented, and is of higher priority than play. The fact that these 
findings are consistent with literature published over 20 years ago reflects a larger belief that work is something that requires completion, and must be completed before engaging in more desirable play activities.

Work is hard. Children's categorizations of work were often surprising and unexpected. One would assume that the dramatic centre would be viewed as play, given the free, social, and active nature of the centre. However, this was not the case with Elizabeth, who viewed the hairdresser doll in the dramatic centre as work. Although this response may seem surprising, it was her rationale that provided insight into why she viewed this activity as work. Elizabeth stated it was work "because her hair is too strong...you just have to hold her neck and then you have to brush strong and hard." The use of the word "hard" when describing her actions suggests that brushing through the doll's hair involved physical force, and that it may have been a difficult task. The physical task of holding the doll in place while brushing through her tangled hair, which most likely required force, may have led Elizabeth to view the activity as work rather than play. Similar to the children discussed in previous sections, Elizabeth may have associated the physical labour involved in brushing the doll's hair with work. It is also a possibility that Elizabeth viewed the hairdresser activity as work, as the task had an end goal of brushing through the doll's hair to remove the tangles.

Projector also shared an unexpected response when describing painting. When sharing why he believes painting is work, Projector stated, "because it's hard" and "it's for a long time." Although painting is an activity that is not typically associated with work, as it usually involves creativity, imagination, and freedom of expression, the difficulty and lengthiness of the task may have led Projector to view it as work. Similarly, Pink referred to the level of difficulty when describing the water table that she viewed as work, because "we do experiments, and you work 
hard by filling up the water." This finding also reinforces the association between work and physical labour, as filling up the water may involve physical force. Responses from these three children indicate recognition that work is difficult or challenging, as all three children used the word "hard" in their descriptions of work. The association between work and tasks that are difficult and challenging is consistent with the findings from the study by Chapparo and Hooper (2002) who found that children perceive tasks as work depending on the level of difficulty. If the children perceived the task as challenging and beyond their ability, it was viewed as work.

For each of the photographs, children were asked if they enjoy engaging in/with the activities, learning centres, or materials in the photographs. When Elizabeth was asked if she enjoys working with the hairdresser doll, she shared, "no it's too hard." Similarly, when describing whether or not he enjoys painting, Projector stated, "no I don't, it takes too long." Findings from Elizabeth and Projector have indicated that these children did not enjoy the activities due to the level of difficulty. With an understanding that children believe work is something that is difficult or challenging, as well as knowledge that children may not enjoy an activity that they perceive as being difficult, educators may use this knowledge as an indication of when to provide support for children.

It also appears from the findings that Elizabeth, Projector, and Pink have their own subjective and individual reasons as to why they believe an activity, learning centre, or material is work and/or play. Although adults may perceive an activity to be play-like, or work-like, children may not always share the same belief. Children's views appear to be based on individual experiences and contextual conditions. According to Howard et al. (2006), play is best understood not as an observable behaviour, but rather the playful feeling children experience when engaged in an activity. What may appear to be play-like to adults may be viewed as work 
by children based on environmental and emotional cues including the children's perceived difficulty of the task. As educators, it is not possible to fully understand the nature of children's play, as we are not the primary actors. These findings further highlight the importance of exploring children's perceptions of work and play, as they are crucial for formulating a more indepth understanding of play.

Work involves thinking. In addition to work being challenging and involving physical labour, findings also show that the children in this study attributed cognitive effort to activities, learning centres, and materials that they viewed as work. Four children made reference to cognitive effort when describing work. Optimus viewed the book centre as work, stating, "I feel like I'm working by reading...because I have to think in my small little brain." Optimus said that he is "looking at words and figuring out what two different sounds make." For Optimus, reading books involved using his brain to think and figure out the sounds of the letters; thus viewing this activity as work. Jaclyn and Pony also referred to thinking when describing work. Jaclyn viewed the science centre as work, because it is an area where you "think about what you want to discover." Pony believed the science centre was work because "you think about stuff." Pink also made an association between cognition and work, stating she believed the book centre is work because "when you read books it makes you smarter."

The association between work and cognitive effort is consistent with previous literature, which indicates that children's categorizations of work and play are closely related to their perception of the cognitive demand of the activity (Wing, 1995; Liu-Yan et al, 2005). Wing (1995) found children's explanations of activities that they viewed as work often involved a level of thinking or concentration. Similarly, four children in the current study made reference to 
cognitive effort when describing why they believed an activity, learning centre, or material was work.

In contrast, only one child mentioned cognitive effort in reference to play. In fact, her rationale as to why she believed a centre was play was due to the cognitive aspect. Black viewed the math and cognitive centre as play, describing it as a centre involving puzzles, dominos, and matching activities. When asked to explain her reasoning, Black referred to the cognitive aspect of the activities, stating that you "get to think and use your brain." This response is significant, and necessary to report, as it is contradictory of the beliefs of the four children mentioned above. It is also important to highlight this response, as it is contradictory of the literature stating that young children are typically unaware of the cognitive demand in play activities.

It is necessary to consider how at such a young age, these children have made an association between work and cognitive effort. It is evident that all activities, learning centres, and materials in the kindergarten classrooms involve cognitive effort, whether or not the children viewed them as work or play. However, with the exception of Black, cognitive effort was only associated with activities that children viewed as work. This finding suggests that the association between work and cognitive effort is an idea that children have been exposed to or observed. Similar to previous findings, it would be beneficial to further explore how this idea has become part of children's perceptions. This finding supports the literature and further highlights children's association between work and cognitive effort. Although these children are in a play-based learning environment, where cognitive effort is evident throughout all activities and tasks, children still hold a belief that cognition is related to work.

We have to work. When describing activities, learning centres, and/or materials that children viewed as work, the children's choice of language suggested that the nature of work was 
obligatory. Children described work as activities they "have" or "need" to do. Darth Vader viewed the math and cognitive centre as work because "we have to work" when in that centre. Similarly, Diego shared that when in the book centre, "we have to read books." Pink viewed the computer as work, "because you have to answer some questions...like four take away two." For Pink, the computer was work because it involves answer mathematical questions. Luke Skywalker also viewed the creative arts centre as work, "because I need to make something." The use of the word "need" further suggests an obligatory characteristic of work.

Superman, who viewed the creative arts centre as work, further demonstrated the obligatory nature of work in his responses. In Superman's classroom, the table in the creative arts centre is where children engage in teacher-directed activities. When Superman was asked to explain what he does in the creative arts centre, he stated, "we do that as our work...I don't choose, we just have to go there," indicating that it is something that is required of him. Given that the activities in this centre are teacher-directed and structured, there may be minimal or no opportunity for freedom of choice. The use of the word "have" in the children's responses indicates that the activities, learning centres, and materials they view as work were required.

It is important to consider how the ideas of having and needing to work became a part of children's perceptions. Perhaps this is the language children have heard their parents and/or other adults use on a daily basis. "Mommy has to go to work today" or "Daddy needs to work" are phrases children often hear from their parents. These phrases suggest that work is an obligation and something that is required of them, rather than willingly chosen. It is also possible that this is the language used by the educators in the children's classrooms when referring to activities that children perceive as work. Although educators may be unaware of their use of language, it is often internalized and repeated by children. This finding urges educators working with children 
to consider how the language they use impacts, and may become part of children's perceptions. It is also possible that the obligatory nature of an activity is not always imposed by the educator, but mandated buy by the nature of the task. Pink stated that the computer was work because she had to answer mathematical questions. The task requires the completion of the questions; therefore the nature of the task may have influenced Pink's perception of the computer as obligatory.

Findings are consistent with previous studies that have indicated that children refer to the compulsory nature of an activity or task when distinguishing between work and play (King, 1982; Capparo \& Hooper, 2002; Keating, et al., 2000). According to the literature, children view work as something that involves limited choice, and is done in response to teacher instruction. Similarly, the children in this study demonstrated an awareness of the obligatory nature of work through their use of language. Capparo and Hooper (2002) found that the children in their study considered activities or tasks with minimal choice as work, and that they are less desirable than freely chosen activities. With an understanding that children view work as obligatory and that it may be less desirable, as well as an understanding of how the language used by educators may influence children's perceptions of activities, educators can be conscious of their choice of language. If educators use language that encourages and supports children's freedom and choice in activities, they may appear more desirable to children.

\section{Characteristics Children Attribute to Play in their Classrooms}

It appears from the findings that commonalities exist in the characteristics children attribute to activities, learning centres, and materials they view as play. Characteristics children attributed to play are discussed in the following sub-themes; we get to play whatever we want, pretend play and playing with toys, and I like to play because it's fun. 
We get to play whatever we want. Findings indicate that children associated play with activities that are voluntary and involve freedom of choice. Five children described play as something that they choose to do, rather than something they are obligated to do. Jaclyn viewed the water table as play, "because I just get to play stuff." Similarly, Black stated, "you get to play on the computers... you get to play different games." Luke Skywalker believed that the books are play, "because you get to read books and people read to you." The use of the word "get" suggests that these children view play as involving freedom of choice. The language used by children to describe activities, learning centres, and materials that they view as play was significantly different than the language used to describe work. As opposed to work as something children have to do, play was something children get to do.

The association between play and freedom of choice was also evident in Black's rationale for why she believed the chalkboard was play, as she stated, "because you get to do things that you want to do and you're not building anything." Similarly, when explaining why he believes the computer is play, Dooda shared, “because it's playing whichever game we want." Diego also made reference to choice when describing play. In Diego's classroom, the drawing centre is used for reading and writing groups led by the educators. Diego viewed the drawing centre as both work and play, and stated that the play aspect of the centre was "drawing whatever you want." The work aspect was the group time, where "the teachers do reading and writing with the kids." For these children, choice and freedom were defining features when describing why they viewed an activity, learning centre, or material as play.

Children's responses not only indicated choice, but also an element of control. Being able to do "whatever you want" implies that the activity not only involves choice, but that the child has control over the task. These findings are consistent with previous studies that have found 
children often classify activities as play when they are voluntary and freely chosen, whereas activities that are assigned or directed by the teacher are viewed as work (King, 1979; Howard, 2002; Howard et al., 2006; Chapparo \& Hooper, 2002). Findings from current literature on educators' perceptions of play have also indicated that educators believe play involves children's willingness and control (Sherwood \& Reifel, 2010; Ranz-Smith, 2007; Wu \& Rao, 2011). The findings from this study add to the body of literature on perceptions of play, indicating that both educators and children believe choice and control to be defining characteristics of play.

Pretend play and playing with toys. Findings indicate that when describing play, children often made reference to the active involvement in play activities. Three children referred to play as involving an element of fantasy and pretend play. Pretend play is a form of play where children communicate with one another using language, gestures, and objects to tell and reenact stories (ELECT, 2006). Pretend play is generally an unstructured activity and encourages children's creativity through manipulation of materials and social interactions. This was evident in a number of the children's responses, as they referred to play as an activity that involves pretending. Jaclyn described the dollhouse as an activity where "we pretend that's the mom and if you have the baby doll then you can be the baby." Black reported that when playing with the dollhouse she, "pretend[s] that the little people are alive and move around the house." Similarly, Pink referred to the pretend aspect involved in play activities, sharing that she bakes pretend cookies with playdough. As presented in the previous section, the four children who photographed the dollhouse all viewed it as play as it incorporates active involvement with manipulation of materials, as well as pretend play.

When describing play activities, four children also made reference to their active engagement with toys. The materials children described as toys all involved active involvement 
(e.g., lego, materials at the water table, musical instruments). Luke Skywalker viewed the dollhouse as play, and when asked why, he stated, "because you get to play with all the toys." Diego believed that he played while at the water table, "because the water is play and there's toys" (e.g., buckets, containers, boats). Elizabeth and Ariel also stated that they believed lego was play because they believed it was a toy. For these children, the presence of toys was a defining characteristic when distinguishing between work and play activities.

Although it is not surprising that children associated play with the presence of toys, this finding was necessary to highlight, as it was a recurring theme throughout the four children's responses. After examination of the materials that children viewed as toys, it is apparent that these materials involve children's control and freedom. The materials that these children described as toys are open-ended materials that allow for children's control over the activity. With the knowledge that children associate play with activities, learning centres, and materials that involve freedom of choice, it is possible that children have made an association between toys and play due to the fact that they are open-ended, unstructured, and allow for freedom of exploration. It is also possible that the children's association between toys and play was influenced by the socio-economic status of the children and the climate of the kindergarten classrooms. Findings from the study by Anthamatten et al. (2012) found that when describing play, low-income children often referred to areas of the built environment (e.g., parks, backyard), rather than material objects, as they did not have access to such materials. On the contrary, the children in the present study are enrolled in kindergarten programs where they have access to a variety of materials and toys. Perhaps the socio-economic status of the children was an underlying factor influencing children's perception of toys as play. 
The association between play and active involvement is consistent with previous literature indicating that children often view activities that incorporate physical involvement and manipulation of materials as play (Liu-Yan et al., 2005; Wing, 1995; Cooney et al., 2000; Robson, 1993). Additionally, Liu-Yan et al. (2005) found that the presence of toys was a crucial factor influencing children's distinctions between work and play. This finding further supports the literature and highlights children's association between play and active engagement.

I like to play because it's fun. It appears from the findings that activities, learning centres, and materials children viewed as play were often associated with positive feelings, including playfulness and enjoyment. Having fun was a characteristic mentioned by seven children when describing why they believed an activity, learning centre, or material was play. Projector viewed both books and playdough as materials he played with and described both as "fun." Similarly, when asked why she believes puzzles are play, Pony stated, "because it's fun.” Ariel also mentioned fun when describing activities, learning centres, and materials she viewed as play, including the dollhouse and radio.

In addition to having fun, children indicated that they "like" or "love" an activity, learning centre, or material when explaining why they were playing rather than working. Pink stated that she plays at the drawing centre "because I like doing it." Darth Vader also expressed that he liked to play when on the computer. When Hot Head was asked what he does in the dramatic centre, he stated, "we play...fun stuff that we like." After sharing that she believes markers are play, Ariel's rationale indicated an awareness that play is something that is not only enjoyed by herself, but everyone else as well. When asked why Ariel believes the markers are play, she stated, "because it's fun... because people love doing it." 
The association between positive feelings and play is consistent with the literature, which indicates that one of the most prominent characteristics of play reported by children is having fun, being happy, and doing things they enjoy (Wing, 1995; Rothlein et al., 1987). When describing activities, learning centres, and materials that the children perceived as work, they did not attribute having fun, or state that they liked or loved the activities.

Not only did children express that they enjoyed playing, one child shared that doing work was something that he did not enjoy. Optimus viewed the blocks as play, stating, "I like playing with them, I don't like working with them.” This response not only indicates that Optimus perceives a distinction between work and play, but also feels playing with the blocks is more enjoyable than working with them. With knowledge that children associate play activities with fun and enjoyment, as well as knowledge that children often find work difficult or challenging, educators can attempt to bring this fun aspect to work activities, making them more enjoyable for children.

\section{Work, Play, and Learning}

During the interviews, children were asked if they believe they learn while engaged in the activities, learning centres, and/or materials they had photographed. Of the 42 activities children photographed and viewed as work, $71 \%$ of the responses indicated that they believed they were learning while engaged in the activities. Of the 72 activities, learning centres, and materials that children viewed as play, $47 \%$ were identified as involving learning. Findings indicate that learning was more often associated with activities children viewed as work, than those viewed as play.

When children were asked if they believe they are learning while engaged with the activities and materials, or in the learning centres they had photographed, the majority of children 
responded with a simple yes or no answer. When the researcher asked the children to explain what they believed they learn, children often stated that they did not know, or that they learn "stuff" or "things." There were also a number of children who shared what they believe they learn while engaged in activities, learning centres, and/or materials they viewed as work. Darth Vader described the creative arts centre as work, and stated, "I am learning to make stuff." Similarly, Blue shared that she believed the sandbox was work and that she is "learning to build stuff." These findings not only indicate that children recognize that they are learning while engaged in activities they perceive as work, they also reinforce the association between work and building/making something.

Pink further demonstrated the association between work and learning when she stated that the computer, which she viewed as work, involved "learning math questions." When describing the drawing centre, Pink shared that she works and she plays there. The play aspect of the drawing centre was drawing pictures, and the work aspect was "doing books." When asked if she learns while at the drawing centre, Pink stated, "yeah, when I do books I am.” Pink did not believe she was learning while drawing; learning only took place during the aspect of the activity she viewed as work. Optimus also stated that he learns while reading books because "I'm learning how to read." Similarly, Jaclyn stated that she believed that she learns when in the science centre, because she learns "how to hear seashells in your hear." Jaclyn shared that when in the science centre she learned that you could hear the sounds of the ocean in the seashell. Blue also recognized the creative arts centre as involving learning, stating she believes she is "learning how to make art."

Furthermore, findings indicate a perceived dichotomy between play and learning. Children associated work with learning, whereas play was associated with not learning. Black shared that 
she plays with the dollhouse and that "play is not something you learn." Similarly, Luke Skywalker believed that he does not learn while playing at the dollhouse, because "there is nothing there to learn." Hot Head viewed the dramatic centre as play, and when asked if he believed he learns while in this dramatic centre, he stated, "no, I'm playing." Similarly, after Darth Vader labeled the block centre as play, when asked if he learns he stated "no...we're just playing." Dooda reported a similar response after sharing that he believes the drawing centre is work, Dooda stated, "I only learn...I don't play there.” Dooda expressed that he only learns and does not play in the drawing centre, indicating a clear distinction between what he believes to be learning and what he believes is play. This was also evident in Superman's response, as he stated that he does not learn while in the dramatic centre because "it's not work." Superman believed that he was not learning because the dramatic centre is not work; therefore, reinforcing the association between play and not-learning. Superman also responded similarly to the puppet centre, which he viewed as play, and did not involve learning because "it's not work." This finding suggests that these children do not think that play and learning can co-exist within one activity, and that they do not learn during play. When asked if they learn while engaged in activities they viewed as play, three children made comments stating that they were "just playing" and not learning. The use of the word "just" suggests that children believe play is not important, and that it is merely play.

In contrast, three children expressed beliefs that learning occurs during play. Projector described the book centre as play, and when asked if he believes he learns, he stated, "yes...learning about different kinds of things." Similarly, Jaclyn viewed the dollhouse as play and stated "I'm learning to put furniture in the house because I have a house and people live at the bottom." Optimus also shared a response that indicated he learns while engaged in play; 
however, he seemed somewhat unsure. After stating that he believes the guitar instrument was play, he shared that he thinks he is "sort of learning to sing new songs." When asked what he meant by "sort of" learning, Optimus said, "because it's just sing-playing." Although Optimus stated that he believed he learns while engaged in play, his response indicated that play only involves "sort of" learning, and that he was not fully learning while engaged in singing.

These findings are consistent with Howard's study (2002) who found a positive correlation between play and not learning and work and learning, and Robson (1993) who found that children do not associate play with learning. Although the activities that children viewed as play involve learning, the majority of children were not aware of the learning opportunities embedded in play activities. It is possible that this idea of learning while working and not while playing is linked to the children's perceptions of the value of play within their classroom. It also may be an indication of children's' perceptions of the status of play in relation to work activities that involve learning. In play-based programs, where play is valued as a medium for learning, it is important that children are aware that learning takes place in different types of activities. It is also important to consider why these children perceive play and learning as separate entities, and how the association between play and not learning became part of their perceptions. Literature on educators' perceptions of play has indicated that educators often struggle with implementing play-based programs due to tensions between traditional and progressive beliefs, as well as meeting curricular demands (Ranz-Smith, 2007; Keating, 2000). Children's association between working and learning, and play and not learning, may be related to the tensions experienced by the educators, and the types of activities that are emphasized and valued within their classrooms. 


\section{Characteristics Children Attribute to Both Work and Play}

When completing the spider diagram categorization task, the children did not label every activity, learning centre, or material as either work or play. Findings show that of the 114 photographs that were viewed, 22 were labeled as both work and play. Children viewed certain activities as having both play and work-like characteristics. They also identified and explained which aspects of the activity, learning centre, or material were work, and which were play.

According to the literature, children who are in play-based constructivist environments tend to blur the lines between work and play, while children in structured, teacher-centered environments have a clear distinction between work and play (Cooney et al., 2000; Howard, 2002). Findings from the present study are somewhat inconsistent with the literature. Although the children in the present study are enrolled in play-based kindergarten programs, findings show that they did not blur the lines between work and play. Although children often identified one activity, learning centre, or material as both work and play, they were able to identify which aspects of the activity they viewed as work, and which aspects they viewed as play. Children were able to make clear distinctions between work and play and recognized different characteristics of an activity to be associated with work, and others as play.

Wing (1995) proposed a work-play continuum suggesting that children do not see all activities at opposite ends of a spectrum, but rather some elements of the same activity lead children to label it as work, and others as play. The findings from the present study support the continuum approach proposed by Wing (1995), as many children recognized activities, learning centres, or materials as both work and play. Although the children recognized that certain activities, learning centres, and materials have both play and work-like properties, there were clear distinctions between what was considered work, and what was considered play. 
Of the 16 children, only one child indicated a belief that the lines between work and play were blurred. This was evident in Dooda's response, who shared his belief that work and play co-exist within one activity and are not always distinct from one another. Dooda explained that the sandbox is "playing and we are also working...the work is the play, they are connected together." Although Dooda's response suggests that he has blurred the lines between work and play, the majority of the children demonstrated clear distinctions in the characteristics they attributed to work, and the characteristics they attributed to play.

\section{Children's Definitions of Work and Play}

Through an exploration of the characteristics children attributed to work and play, one of the aims of the present study was to begin to develop a definition of what is considered work, and what is considered play based on the perspectives of the children in this study. According to the children's ideas, work can be defined as tasks or activities that are challenging, involve physical labour, and often result in a final product. Play, from the perspective of the children in this study, can be defined as enjoyable activities that are freely chosen, involve pretend play, and the manipulation of materials children perceive as toys. 


\section{Chapter V: Conclusion}

The aim of the present study was to explore children's perceptions of work and play in their kindergarten classrooms. Findings have shown that the way in which children categorize activities, materials, and learning centres within their classrooms is based on their own individual experiences. Findings from the study have also indicated that children have clear distinctions between the characteristics they attribute to work, and the characteristics they attribute to play.

This research study examined children's perceptions of work and play using a unique methodological approach that aimed to give children a sense of control in the research process by allowing them to participate in data collection, as well as preliminary data analysis. The majority of current research on children's perceptions of play has employed methodological tools that do not provide children with the opportunity to voice their opinions and a provide rationale for their views (e.g., observations, categorization tasks without interviews). The methodology employed within this study gave children a sense of control in the research process, and was successful in eliciting children's perceptions of work and play.

The findings from the present study have addressed the gap in recent research on children's perceptions of play by adding recent findings. The findings are also consistent with existing literature; thus, reinforcing the characteristics the children have attributed to work and play. The fact that children's perceptions of work and play have remained consistent for over 20 years suggests that these perceptions and beliefs may be widely held within society and education. Despite the current emphasis on play-based learning in early childhood education, these children still appear to perceive clear distinctions in characteristics they attribute to work and to play. 


\section{Implications for Practice}

Research has indicated that many educators support the theory of play-based learning, yet they struggle with the implementation (Ranz-Smith, 2007; Keating, 2000). An understanding of the characteristics children attribute to play (e.g., freedom of choice, active involvement, positive feelings) may assist educators when implementing play-based programs. As stated by McInnes et al. (2011), children's play is not simply an observable behaviour, but rather the feelings of playfulness when engaged in an activity. What may appear to be play to adults, may not feel like play to children. Therefore, utilizing a definition of play that is based on children's perceptions will assist in creating more meaningful play experiences.

Findings from the study have indicated children's perceived association between work and learning, and play and not learning. In a play-based environment, where the philosophical belief is that play is a medium for learning, it is important that children are aware that learning takes place in many different forms, and not simply during activities that they perceive as work. It is also important that educators communicate this to parents whose children are enrolled in playbased programs. The findings from this study also urge educators to be aware of the attitudes and ideas they communicate to children through provision of materials, the types of activities/tasks that are valued and encouraged, as well as their choice of language. It is important for educators to be conscious of their choice of language, as their verbal expressions may be internalized and become part of children's perceptions. As educators working with young children, an understanding of children's perceptions encourages an awareness of their own perceptions, as adults are often mediators of messages to children. 


\section{Limitations}

As a researcher, in order to establish rapport and gain an understanding of children's views and experiences, it is beneficial to spend a prolonged amount of time with participants prior to data collection (Punch, 2002). Due to the time limitations of the major research paper, repeated visits prior to data collection were not possible. It is also recommended that member checking is used as a tool to add to the validity of the study and ensure the accuracy of the findings (Creswell, 2009). This was also not possible due to the time limitations of the major research paper; however, steps were taken during data collection to ensure children's responses were recorded accurately. Additionally, the study involved a total of 16 participants; therefore, the results are not generalizable to all children in play-based kindergarten programs. The findings provide insight into the perceptions of the 16 children who participated in the study, built on previous research on children's perceptions of play, and posed questions for further research.

\section{Directions for Further Research}

Due to the time limitations and scope of the major research paper, certain factors could not be explored. This study has provided insight into children's perceptions of work and play and has posed questions regarding the possible factors that may have influenced children's views.

Directions for further research include the examination of potential factors that may influence children's perceptions of work and play. It would be beneficial to examine educators' perceptions of work and play to determine if children share similar beliefs, and whether or not children's perceptions are influenced by educators' beliefs. It would also be valuable to explore whether the educators' choice of language influences children's perceptions of work and play. Directions for further research should also include an examination of children's perceptions of 
work and play in non-play-based early childhood settings to examine the possible influence of the type of program philosophy on children's perceptions of work and play.

Although the children in the present study were enrolled in play-based kindergarten programs, they have demonstrated clear distinctions between the characteristics they attribute to work and to play. Given the complexity of understanding play within a classroom setting, further research is needed to examine the concept of play-based learning. 


\section{References}

Anthamatten, P., Shao-Chang Wee, B., \& Korris, E. (2012). Exploring Children's Perceptions of Play Using Visual Methodologies. Health Education Journal, 72(3), 309-318.

Balen, R., Blyth, E., Calabretto, H., Fraser, C., Horrocks, C., \& Manby, M. (2006). Involving children in health and social research. Childhood, 13(1), 29-48.

Bennett, N., L. Wood, and S. Rogers. 1997. Teaching through play. Buckingham: Open University Press.

Bertrand, J., Dickinson, P., Ontario. Ministry of Children and Youth Services, \& Ontario. Best Start Expert Panel on Early Learning. (2006). Early learning for every child today: A framework for Ontario's early childhood settings

Braun, V., \& Clarke, V. (2006). Using thematic analysis in psychology. Qualitative Research in Psychology, 3(2), 77-101.

Ceglowski, D. (1997). Understanding and Building upon Children's Perceptions of Play Activities in Early Childhood Programs. Early Childhood Education Journal, 25(2), $107-12$

Chapparo, C. J., \& Hooper, E. (2002). When is it work? Perceptions of six-year-old children. Work (Reading, Mass.), 19(3), 291.

Christensen, P. H. (2004). Children's participation in ethnographic research: Issues of power and representation. Children \& Society, 18(2), 165-176.

Christensen P, James A. 2008. Research with Children ( $2^{\text {nd }}$ ed). Falmer Press: London.

Clark, A., Moss, P., National Children's Bureau, \& Joseph Rowntree Foundation. (2001). Listening to young children: The mosaic approach 
Coad, J., \& Evans, R. (2008). Reflections on practical approaches to involving children and young people in the data analysis process. Children \& Society, 22(1), 31-52.

Cooney, M. H., Gupton, P., \& O'Laughlin, M. (2000). Blurring the Lines of Play and Work To Create Blended Classroom Learning Experiences. Early Childhood Education Journal, 27(3), 165-71.

Creswell, J. (2009). Research Design: Qualitative, quantitative, and mixed method approaches. Thousand Oaks: Sage Publications Inc.

Danby, S., \& Farrell, A. (2004). Accounting for young children's competence in educational research: new perspectives on research ethics. The Australian Educational Researcher, $31(3), 35-49$.

Di Santo, A., \& Kenneally, N. (2012). Outdoor Play in Canadian Early Learning Centres.

Einarsdottir, J. (2007). Research with children: Methodological and ethical challenges. European Early Childhood Education Research Journal, 15(2), 197-211.

Hill, M., Davis, J., Prout, A., \& Tisdall, K. (2004). Moving the participation agenda forward. Children \& Society, 18(2), 77-96.

Holzman, L. (2009). Vygotsky at work and play. New York: Routledge.

Howard, J. (2002). Eliciting young children's perceptions of play, work and learning using the activity apperception story procedure. Early Child Development and Care, 172(5), 489-502.

Howard, J., Jenvey, V., \& Hill, C. (2006). Children's categorization of play and learning based on social context. Early Child Development and Care, 176(3), 379-393.

King, N. R. (1979). Play: The Kindergartners' perspective. The Elementary School Journal, 80(2), 80-87. 
Keating, I., Fabian, H., Jordan, P., Mavers, D., \& Roberts, J. (2000). 'Well, I've not done any work today. I don't know why I came to school'. perceptions of play in the reception class. Educational Studies, 26(4), 437-454.

Lindon, J. (2001). Understanding Children's Play. Nelson Thornes Ltd: United Kingdom Liu-Yan, Pan-Yuejuan, \& Sun-Hongfen. (2005). Comparative Research on Young Children's Perceptions of Play -- An Approach to Observing the Effects of Kindergarten Educational Reform. International Journal Of Early Years Education, 13(2), 101-112.

McInnes, K., Howard, J., Miles, G., \& Crowley, K. (2011). Differences in practitioners' understanding of play and how this influences pedagogy and children's perceptions of play. Early Years, 31(2), 121-133.

Morgan, H. (1999). The imagination of early childhood education. Westport, Conn.: Bergin \& Garvey.

Matthews, S. H. (2007). A Window on the 'New' Sociology of Childhood. Sociology Compass I, 322-334.

Nutbrown, C. (2008). In Clough P., Selbie P. (Eds.), Early childhood education: History, philosophy and experience. London: SAGE.

Pellegrini, A. D., \& Bjorklund, D. F. (1998). Applied child study : A developmental approach. Mahwah, N.J.: L. Erlbaum.

Piaget, J. (1962). Play, dreams, and imitation in childhood. London: Routledge and K. Paul. Powell, M., \& Smith, A. (2009). Children's participation rights in research. Childhood, 16(1), 124-142. 
Punch, S. (2002). Research with children: The same or different from research with adults? Childhood, 9(3),321-341.

Pui-Wah, D, C. (2004). Articulating contrasts in kindergarten teachers' implicit knowledge on play based learning. International Journal of Educational Research, 41(4). p. 339-352.

Qvortrup (2004). Editorial: The waiting child. Childhood, 11(2), 267-273.

Ranz-Smith, D. (2007). Teacher perception of play: In leaving no child behind are teachers Leaving childhood behind? Early Education and Development, 18(2), 271-303.

Robson, S. (1993). 'Best of all I like choosing time.' Talking with children about play and work. Early Child Development and Care, 92, 37-51.

Rothlein, L., \& Brett, A. (1987). Children's, teachers; and parents' perceptions of play. Early Childhood Research Quarterly, 2(1), 45-53.

Rubin, K. H., Fein, G.G., \& Vandenberg, B. (1983). Play. In Handbook of child psychology: Socialization, personality, and social development, 4, 693-741.

Saracho, O, N., \& Spodek, B. (1998). Multiple Perspectives on Play In Early Childhood Education. State University of New York Press: United States.

Sherwood, S. A. S., \& Reifel, S. (2010). The multiple meanings of play: Exploring preservice teachers' beliefs about a central element of early childhood education. Journal of Early Childhood Teacher Education, 31(4), 322-343.

Spratling, R., Coke, S., \& Minick, P. (2012). Qualitative data collection with children. Applied Nursing Research, 25(1), 47-53.

Takhvar, M. (1988) Play and the theories of play. A review of the literature. Early Childhood Development and Care, 39, 221-244. 
Taylor, S. I., Rogers, C. S., Dodd, A. T., Kaneda, T., Nagasaki, I., Watanabe, Y., \& Goshiki, T. (2004). The meaning of play: A cross-cultural study of American and Japanese teachers' perspectives on play. Journal of Early Childhood Teacher Education, 24(4), 311-321.

UNICEF, Unesco, \& United Nations. General Assembly. (1990). The united nations convention on the rights of the child

Wing, L. A. (1995). Play is not the work of the child: Young children's perceptions of work and play. Early Childhood Research Quarterly, 10(2), 223-247.

Wollheim, R. (1971). Freud. Cambridge University Press: London

Wu, S., \& Rao, N. (2011). Chinese and German teachers' conceptions of play and learning and children's play behaviour. European Early Childhood Education Research Journal, 19(4), $469-481$. 
Appendix A

\section{Supervisor/Manager Approval Form Exploring Children's Perceptions of Work and Play in Kindergarten Classrooms}

Kindergarten children within one classroom at are being asked to participate in a research study. As the supervisor/manager of the centre, I ask that you provide approval for this study to take place within your centre. This form outlines detailed information about the study.

Principal Investigator: Cassandra Calderone, M.A. Candidate, School of Early Childhood Studies, Ryerson University.

Purpose of the Study: The purpose of the study is to examine children's perceptions of work and play in their kindergarten classrooms.

Description of the Study: In a play-based learning environment, children's learning and development is fostered through various play activities. I am interested in examining children's perceptions of work and play, as well as what characteristics they attribute to both work and play. Upon receiving consent from the parents/guardians of children currently enrolled in the kindergarten program, children will be randomly selected to participate in the study by drawing names from a bag. Children will not be selected based on any personal traits, but through an absolutely random process.

\section{How the Information Will Be Gathered:}

Data collection for this study will happen in a number of different ways:

Visual Documentation: Children will be given a digital camera to photograph their classroom. While we are walking through the classroom and taking pictures, we will engage in a conversation about the photographs.

Semi-Structured Interview: Photos will be transferred onto my laptop computer. Children will have the opportunity to look at the photos, and classify them according to whether they work or play in the different areas in the classroom, with the materials, or while engaging in the activities they have photographed. Children will be asked to explain why they play/work in the areas that have been photographed. Each photograph will have a number $(1,2,3 \ldots)$. I will have a paper copy of the number. To make this an interesting activity, the child will take the photo's corresponding paper number and glue it to a picture of a spider. Four legs of the spider will be for play and four legs will be for work.

Audio Recordings: Both the classroom photography tour as well as the semi-structured interview will be audio recorded to ensure accuracy.

Risks or Discomforts: The potential risks of participating in this project are minimal. Some children may feel mildly uncomfortable talking to the researcher and not know how to communicate their feelings, however they will be informed that they may refuse, or decide to end participation at any time. In addition, there is a possibility that while engaging in a dialogue 
with the children, a child may disclose abuse. In the event of this occurrence, I am obligated by law to notify the proper authorities.

Benefits of the Study: Potential benefits of this study include insight into children's perceptions of work and play within their kindergarten classrooms. Findings from the study may inform future practice, planning, and implementation of the program. However, the researcher cannot guarantee that participants will receive any benefits from participating in this study.

Confidentiality: The study will be conducted in a confidential and professional manner. The only two individuals with access to data are the principal investigator, and the principal investigator's academic supervisor, Dr. Di Santo. The recordings of the interviews and photographs will be stored at Ryerson University in a locked filing cabinet in the office of Dr. Di Santo. The recordings, the transcripts of those tapes, photographs, and completed spider pictures will be stored for one year after the completion of the study and then destroyed. Participants will not be identified by name in the transcripts; instead pretend names will be used in the final research paper. An issue of confidentiality may also arise because everyone in the classroom will see which children are participating in the study. However, children in kindergarten classrooms often have visitors (e.g., teacher candidates, therapists, volunteers), and are accustomed to adults being in the classroom. Therefore, confidentiality is not an issue. Children's names will not be linked to any of the data or their responses.

Voluntary Nature of Participation: Participation in this study is voluntary. The parent(s)/guardian(s) of children enrolled in the kindergarten program have the option of providing consent for their child(ren) to participate in the study. Parental consent does not mean that the children are obligated to participate. Once a child is selected, and chooses to participate, he or she is free to withdraw consent and stop participation at anytime without penalty. If any of the participants decide to withdraw from the study, any data/information that he or she has provided will be removed from the data set.

Questions about the Study: If you have any questions about the research now, please ask. If you have questions later about the research, you may contact:

Principal Investigator: Cassandra Calderone

e-mail: cassandra.calderone@ryerson.ca

phone: 416 979-5000 ext. 4576

Supervisor: Dr. Aurelia Di Santo

e-mail: disanto@,ryerson.ca

phone: 416 979-5000 ext. 4576

If you have questions regarding your rights as a human subject and participant in this study, you may contact the Ryerson University Research Ethics Board for information.

Research Ethics Board

c/o Office of the Vice President, Research and Innovation

Ryerson University, 350 Victoria Street, Toronto, ON

M5B2K3

416-979-5042 


\section{Agreement:}

Your signature below indicates that you have read the information in this agreement and have had a chance to ask any questions you have about the study. Your signature also indicates that you agree to allow this study to occur within

You have been given a copy of this agreement.

$$
\text { (name of school) }
$$

\section{Name (please print)}

Signature

Signature of Investigator
Date

Date 
Appendix B

\section{Parental Consent Agreement Exploring Children's Perceptions of Work and Play in Kindergarten Classrooms}

All children currently enrolled in your child's kindergarten classroom at , are being asked to participate in a research study. As the parent(s)/guardian(s) of a child in the program, you are receiving this information letter which describes the study. Before providing consent for your child to participate, it is important that you read the following information and ask as many questions as necessary to be sure you understand what is involved in this project.

Principal Investigator: Cassandra Calderone, M.A. Candidate, School of Early Childhood Studies, Ryerson University.

Purpose of the Study: The purpose of the study is to examine children's perceptions of work and play in their kindergarten classrooms.

Description of the Study: In a play-based learning environment, children's learning and development is fostered through various play activities. I am interested in examining children's perceptions of work and play, as well as what characteristics they attribute to both work and play. Upon receiving consent from the parents/guardians of children currently enrolled in the kindergarten program, children will be randomly selected to participate in the study by drawing names from a bag. Children will not be selected based on any personal traits, but through an absolutely random process.

\section{How the Information Will Be Gathered:}

Data collection for this study will happen in a number of different ways:

Visual Documentation: Children will be given a digital camera to photograph their classroom. While we are walking through the classroom and taking pictures, we will engage in a conversation about the photographs.

Semi-Structured Interview: The researcher will engage in an informal, open-ended conversation with the children, asking questions about the photographs they have taken. Photos will be transferred onto the researcher's laptop computer. Children will have the opportunity to look at the photos with the researcher, and classify them according to whether they work or play in the different areas in the classroom, with the materials, or while engaging in the activities they have photographed. Children will be asked to explain why they play/work in the area that has been photographed. Each photograph will have a number $(1,2,3 \ldots)$. The researcher will have a paper copy of the number. To make this an interesting activity, the child will take the photo's corresponding paper number and glue it to a picture of a spider. Four legs of the spider will be for play and four legs will be for work.

Audio Recordings: Both the classroom photography tour as well as the semi-structured interview will be audio recorded to ensure accuracy.

Risks or Discomforts: The potential risks of participating in this project are minimal. Some 
children may feel mildly uncomfortable talking to the researcher and not know how to communicate their feelings, however they will be informed that they may refuse, or decide to end participation at any time. In addition, there is a possibility that while engaging in a dialogue with the children, a child may disclose abuse. In the event of this occurrence, I am obligated by law to notify the proper authorities.

Benefits of the Study: Potential benefits of this study include understanding children's views about when and where they work and play in their kindergarten classrooms. By exploring children's views of their experiences within the program, knowledge will be generated that may help educators plan and offer activities that foster children's learning.

Confidentiality: The study will be conducted in a confidential and professional manner. The only two individuals with access to the data are the principal investigator, and the principal investigator's academic supervisor, Dr. Di Santo. The recordings of the interviews, and photographs will be stored at Ryerson University in a locked filing cabinet in the office of Dr. Di Santo. The recordings, the transcripts of those tapes, photographs, and completed spider pictures will be stored for one year after the completion of the study and then destroyed. Neither you, nor your child will be identified by name in the transcripts; instead pretend names will be used in my research paper. An issue of confidentiality may also arise because everyone in the classroom will see which children are participating in the study. However, children in kindergarten classrooms often have visitors (e.g., teacher candidates, therapists, volunteers), and are accustomed to adults being in the classroom. Therefore, confidentiality is not an issue. Children's names will not be linked to any of the data or their responses.

Voluntary Nature of Participation: Participation in this study is voluntary. As the parent(s)/guardian(s) of children enrolled in the kindergarten program, you may provide consent for your child(ren) to participate in the study. If you provide consent, your child is not obligated to participate in the study. Your child will be asked if he or she would like to participate, and assent will be obtained prior to your child participating in the study. If your child is selected, and chooses to participate, he or she is free to withdraw assent and stop participation at anytime without penalty. At any particular point in the study, your child has the choice not to answer particular questions or stop participation altogether. If your child decides to withdraw from the study, any data/information that he or she has provided will be removed from the data set. Please note that if you provide consent for your child to participate, it does not guarantee that your child will be involved in the study, as only eight participants will be chosen by random selection.

Questions about the Study: If you have any questions about the research now, please ask. If you have questions later about the research, you may contact:

Principal Investigator: Cassandra Calderone e-mail: cassandra.calderone@ryerson.ca phone: 416 979-5000 ext. 4576

Supervisor: Dr. Aurelia Di Santo e-mail: disanto@,ryerson.ca phone: $416979-5000$ ext. 4576 
If you have questions regarding your child(ren)'s rights as a human subject and participant in this study, you may contact the Ryerson University Research Ethics Board for information.

Research Ethics Board

c/o Office of the Vice President, Research and Innovation

Ryerson University, 350 Victoria Street, Toronto, ON M5B 2K3

416-979-5042

\section{Agreement for your child to participate:}

Your signature below indicates that you have read the information in this agreement and have had a chance to ask any questions you have about the study. Your signature also indicates that you provide consent for your child she is selected. You have been given a copy of this agreement. to participate in the study if he or

You have been told that by signing this consent agreement you are not giving up any of your legal rights.

Parent/Legal Guardian Name (please print)

$\overline{\text { Parent/Legal Guardian Signature }} \overline{\text { Date }}$

Signature of Investigator

Date

\section{Agreement for your child to be audio-recorded:}

Your signature below indicates that you have read the information on confidentiality, and provide consent for the interview with your child to be audiorecorded.

$\overline{\text { Parent/Legal Guardian Name (please print) }} \quad \overline{\text { Date }}$

Parent/Legal Guardian Signature 


\section{Appendix C}

\section{Child Assent Agreement \\ Exploring Children's Perceptions of Work and Play in Kindergarten Classrooms}

$\mathrm{Hi}$, my name is Cassandra.

I was wondering if you could take me on a tour of your classroom, and see all the different activities, learning centres, and areas that you spend time in every day.

Would you like to take me on a tour and take photographs of your classroom?

If the child says yes:

Before we start, I am going to tell you about what we will be doing and what will happen. At the end you can tell me if you still want to do this activity.

1. Would you like to take pictures of different activities, materials, centres, and areas of your classroom? If you don't want to take pictures, you can talk with me about your classroom.

2. Is it okay if I tape our voices while we are talking together? If you want to stop taping our voices, you can say, "stop taping" at any time.

3. Your mom or dad (legal guardian who has given consent) said it's OK for you to do this activity, but if you don't want to, you can say "stop now" whenever you want.

4. If I feel worried about your safety, I will talk to one of your teachers in charge.

5. After you take pictures of the classroom, would you like to look at the pictures on my computer and talk about them?

6. Is it okay if I use your pictures for my project? If you want copies of the pictures when you're done, I will print them for you. If you don't want me to keep your pictures you can say "no" if you don't want me to.

7. Would you like to continue with the activity? If yes, please will you print your name/ make a special mark?

Child's Name/Special Mark

Date: 
Appendix D

\section{Semi-Structured Interview Guiding Questions}

1. Tell me about this picture?

Depending on the child's response questions may include:

2. What do you do in the $?$

3. Do you work or play in the $?$

a) Why is it play/work?

b) Do you enjoy playing/working with this activity/in this area?

4. How often do you play/work here?

5. Do you play/work here by yourself or with your friends?

6. Are you learning when you play/work here?

a) If the child says yes, What have you learned?

a) If the child says no, Why do you think you haven't learned anything?

7. Does your teacher/ECE play/work with you in the ? Tell me about that.

8. Do you choose to do the activity?

9. Do you choose to stop this activity?

10. How do you know when this activity is completed? 